\title{
Beneath the surface: exploring variability in pottery paste recipes within Vinča culture
}

\section{Silvia Amicone ${ }^{1,2}$, Arvin Raj Mathur ${ }^{3,4}$, Rengasamy Deepthi Pavitra ${ }^{4}$, Neda Mirković- Marićc $^{5}$ Ivana Pantović ${ }^{6}$, Julka Kuzmanović-Cvetković ${ }^{7}$}

${ }^{1}$ Competence Center Archaeometry Baden-Württemberg, Eberhard-Karls-Universität Tübingen, Wilhelmstr. 56, 72074Tübingen, Germany (silvia.amicone@uni-tuebingen.de)

${ }^{2}$ UCL Institute of Archaeology, University College London, 31-34 Gordon Square, London WC1H 0PY, United Kingdom

${ }^{3}$ Department of Anthropology, University of Wisconsin-Madison. 1180 Observatory Drive, Madison, WI 53706

${ }^{4}$ Institut für Naturwissenschaftliche Archäologie, Eberhard-Karls-Universität Tübingen.

Rümelinstr. 23, 72070 Tübingen, Germany

${ }^{5}$ Borderlands ARISE Project, Intermunicipal Institute for the Heritage Protection, Trg slobode 1/3 Subotica, Serbia

${ }^{6}$ Gradski Muzej Vršac, Bulevar Žarka Zrenjanina 20, Vršac, Serbia

${ }^{7}$ Narodni Muzej Toplice, Ratka Pavlovića 31, Prokuplje 18400, Serbia

Keywords

Late Neolithic;

Vinča culture;

Material culture;

Ancient technology;

Ceramic petrography;

Regionalism

\section{Abstract}

This study applies thin-section petrography to a wide selection of ceramic and geological samples from four archaeological sites (Belovode, Pločnik, Gradište-Iđjoš, and Potporanj) belonging to both the Neolithic and Chalcolithic phases of the Vinča culture phenomenon (c. 5350 to $4600 \mathrm{BC}$ ) to track intra- and interregional traditions of pottery production with a focus on paste recipes. The results of this study suggest that Vinča pottery manufacturing traditions possess general technical similarities, with significant differences resulting from both environmental constraints and deliberate choices. The comparison of these results with 
those of other petrographic studies in the Neolithic/Chalcolithic Balkans further emphasises that Vinča pottery reflects numerous communities of practice that fall under the umbrella of 'Vinča culture'. This is visible in the varying processes of selecting and manipulating raw materials for ceramic production. Therefore, differences between Vinča pottery assemblages reflect various models of interaction between people and their landscape as well as different technological traditions. Overall, this approach allows us to discuss the problem of similarities and differences in material culture from a perspective that emphasises the socially constructed nature of ceramics.

\section{Introduction}

Regional variability in artefact styles under the broad umbrella of the Vinča culture phenomenon represents an important point in discussions of this Neolithic/Chalcolithic material culture (e.g. Chapman 1981; Garašanin 1979; Lazarovici 1979). Established models of geographical and temporal differences within Vinča material culture rely on variations in vessel morphology and decoration to provide a foundational understanding of the nature of inter-settlement interactions and cultural change (Whittle et al. 2016). However, regional and local diversity in the technical skills of pottery manufacturing and the transmission of production methods (e.g. Roux 2017) has been discussed only to a limited extent within Vinča ceramic studies (e.g. Spataro 2017). The present work addresses this gap in our knowledge by applying ceramic petrography to study the variability in clay paste recipes used at Vinča sites. The primary aim of this paper is to compare ancient potters' use of the landscape natural resources in different subregions of the Vinča culture phenomenon.

Both ethnographic and archaeological research have emphasised that the selection and processing of raw materials for pottery making is an important task that requires both the spatial and temporal engagement of potters with their broader environment. These cultural processes potentially disclose the long-term development of interactions between people and materials across diverse landscapes (Arnold 1993; 2017; Gosselain and Livingstone Smith 2005; Livingstone Smith 2000; Michelaki et al. 2014). As such, the ceramic paste is a useful proxy for tracing the phenomena of regional and supra regional social interaction, as well as the exchange of technological knowledge.

The four sites at the core of this study are located in various regions that comprise the Vinča cultural sphere: Belovode and Pločnik respectively in central and southern Serbia; Gradište- 
Iđjoš and Potporanj in northern Serbia (Vojvodina region; north-centre Banat and south-east Banat respectively). By comparing these results with other petrographic studies carried out on ceramic assemblages from the Balkans (Table 1), similarities and differences in the process of paste preparation within these Vinča communities are discussed and explained considering both environmental constraints and cultural beliefs that are embedded into the task of pottery production. By emphasising the socially constructed nature of pottery production (e.g. Roux 2017), this article uses archaeometric data to study learning and cultural transmission in Neolithic Balkan communities.

\begin{tabular}{|c|c|c|}
\hline Site & Location & Reference \\
\hline Gradište-Idjoš & North-centre Banat (Serbia) & $\begin{array}{c}\text { Mirković-Marić and } \\
\text { Amicone 2019 }\end{array}$ \\
\hline Potporanj & South-east Banat (Serbia) & -- \\
\hline Belovode & Central Serbia & Amicone 2017 \\
\hline Pločnik & South Serbia & Amicone 2017 \\
\hline Maroslele & South-east Hungary & Kreiter et al. 2011 \\
\hline Miercurea Sibiului Petriş & Transylvania (Romania) & Spataro 2014 \\
\hline Parţa & Banat (Romania) & Spataro 2014 \\
\hline Gomolava & Vojvodina (Serbia) & Kaiser 1984 \\
\hline Opovo & South Banat (Serbia) & Tringham et al. 1992 \\
\hline Selevac & Central Serbia & Kaiser 1984 \\
\hline Vinča Belo Brdo & Central Serbia & Spataro 2018 \\
\hline
\end{tabular}

Table 1: List of Vinča sites object of ceramic petrography studies.

\subsection{Archaeological Background}

The Vinča culture is a Neolithic/Chalcolithic material culture that spans a vast area including parts of the northern and central Balkans, including North Macedonia, Serbia, North-east Bosnia, the Vojvodina, southern Transdanubia, the Banat, Oltenia, west Transylvania, and the lower Tisza valley (Figure 1). Numerous attempts to develop a definitive Vinča chronology produced an array of overlapping systems for organising the archaeological sequence of the Neolithic and Chalcolithic Balkans. 


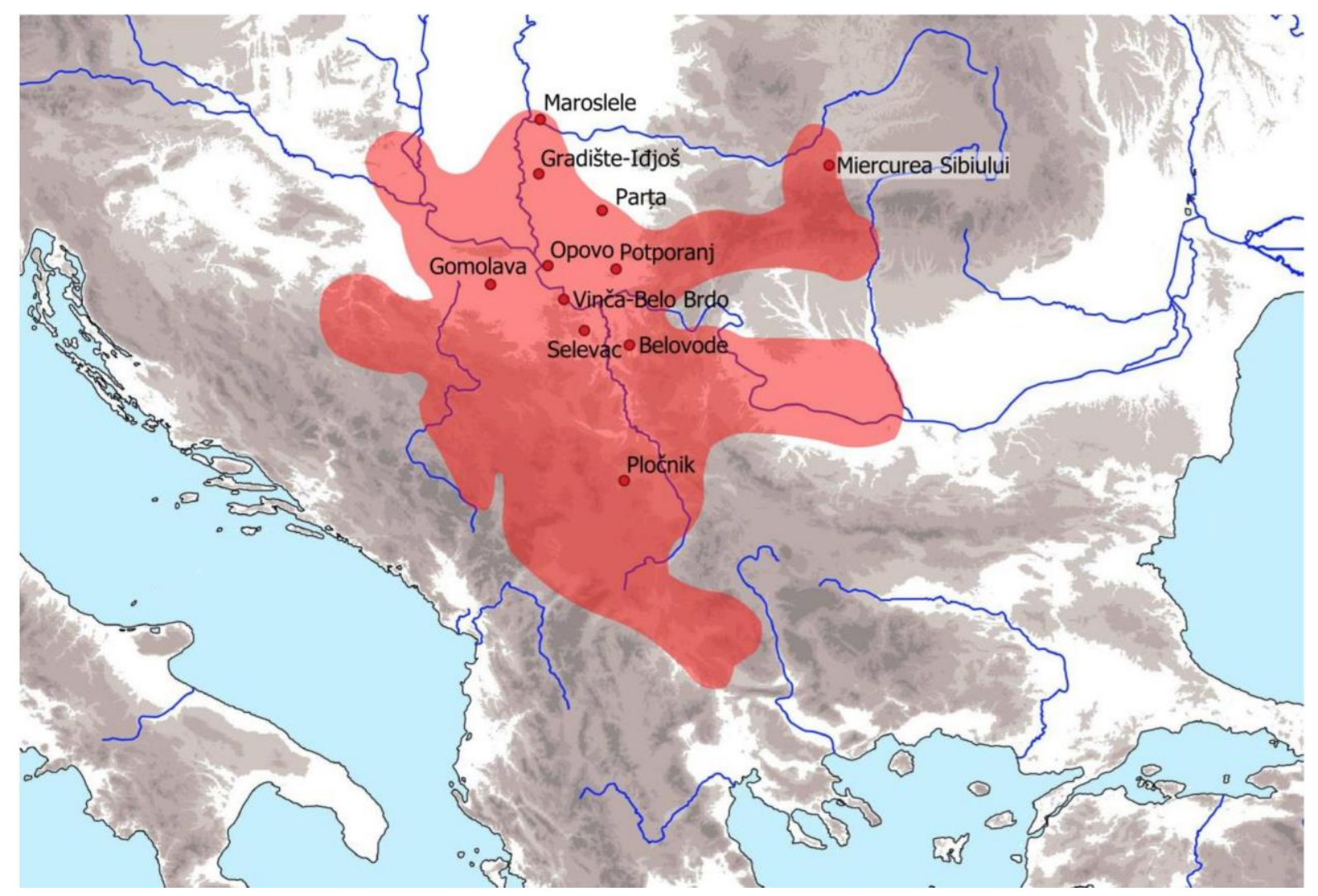

Figure 1: Distribution of the Vinča culture (shaded) and the location of sites mentioned in this study (Map by Lars Heinze and Jugoslav Pedić).

In terms of absolute dates, the estimated duration of the Vinča culture phenomenon spans from c. 5350 to c. 4600 BC (Breunig 1987; Ehrich and Bankoff 1992; Schier 2000; Whittle et al. 2016) and has been divided into different phases according to the observable stratigraphic sequences and typological developments within the ceramic material culture, with the most widely used divisions based on Garašanin (1951; 1979; 1993) and Milojčić (1949) (Figure 2). Garašanin divides the Vinča culture phenomenon into the following tripartite scheme: an early phase named Vinča-Tordoš (I and II), followed by the Gradac phase and three phases of Vinča Pločnik (I, IIa, IIb). The scheme proposed by Milojčić ascribes the following letters to four phases of the Vinča phenomenon: (Vinča A-D), with Vinča A broadly contemporaneous to Vinča-Tordoš I, Vinča B to Vinča-Tordoš II and Vinča C-D to the Gradac phase and Vinča Pločnik. The chronology developed by Garašanin and Milojčić represents the two schemes that are applied in tandem in this paper.

As mentioned earlier, Vinča material culture exhibits regional diversity that becomes especially visible when studying ceramic vessel morphology. The Classic or Serbian variant 
spans across the territory of Serbia proper and the southern portion of Vojvodina, with southern limits close by the confluence of the South and West Morava, while the South Morava variant is placed in the basin of the eponymous river. Further regional variants of the Vinča material culture include the Kosovan, East Bosnian, Transylvanian, Oltenian and Srem-Slavonian ones (Garašanin 1979; Jovanović 1993/1994). Chapman (1981) proposed an alternative scheme for dividing regional variants into smaller areas based on topography and ground catchments. His system comprises thirty-six local areas, grouped in five different provinces defined according to material culture (Serbia and North Macedonia, the Vojvodina, north Bosnia, Oltenia and Transylvania). The challenges associated with understanding this regional variation within the Vinča material culture drives much of the research in the prehistoric Balkans.

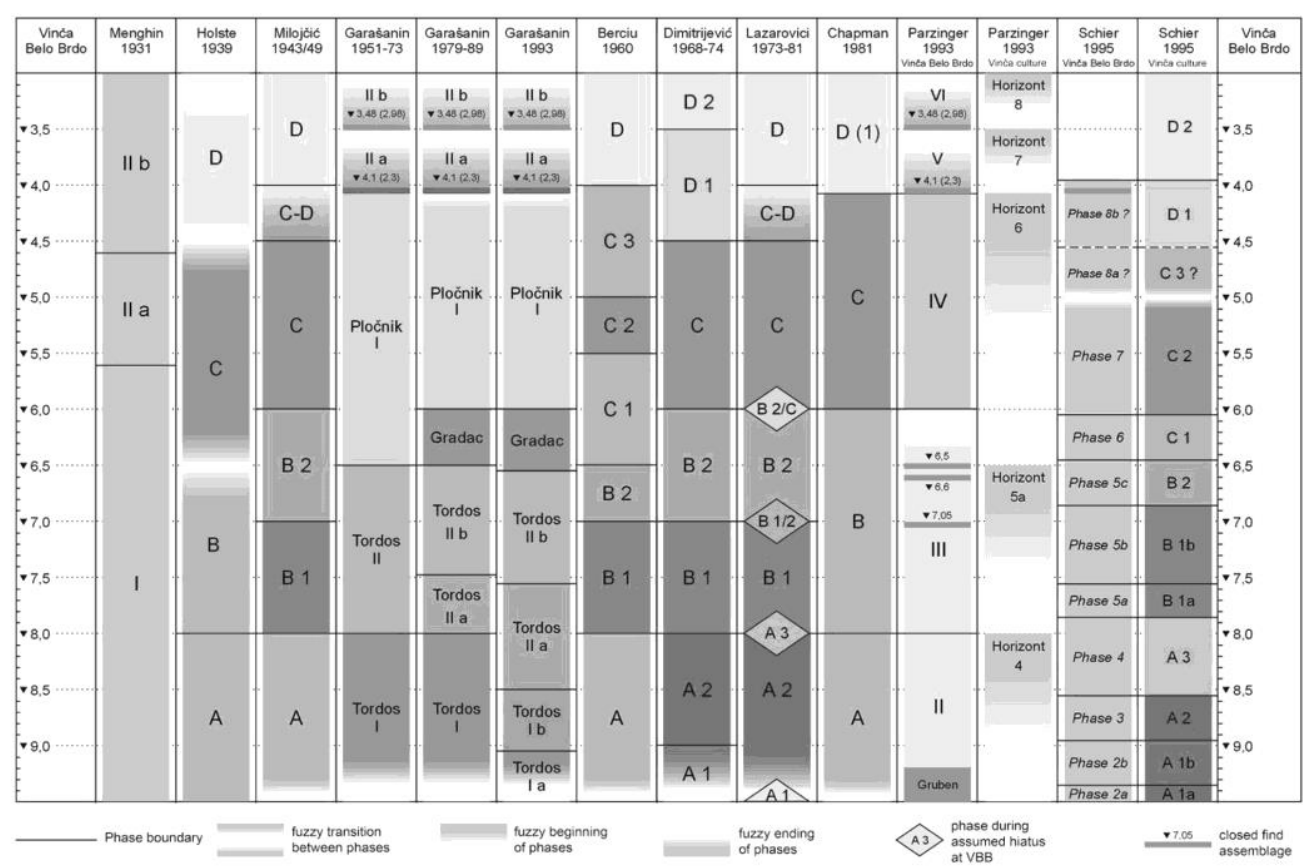

Figure 2: Proposed chronological subdivisions of the Vinča culture phenomenon based on observable stratigraphic sequences and developments in material culture (after Whittle et al. 2016, p. 3, figure 2).

\subsection{Archaeological sites}

The site of Gradište, near Iđjoš (hereafter Gradište-Iđjoš), is situated in the north-centre Banat on an alluvial terrace, approximately $3 \mathrm{~km}$ east of the Tisza river. This Neolithic and Chalcolithic settlement has been excavated on several occasions before and after the Second World War and it is currently investigated by the Borderlands: ARISE project (Maric et al. 
2016; Mirković-Marić and Marić 2017: 9-17). Research on the site has revealed traces of a settlement phase of the Starčevo-Körös culture (second half of the 6th millennium BC), as well as Vinča and Tisza (5200-5000 BC) horizons. In the northern and central portions of the Serbian Banat, the Late Neolithic phase is marked by pottery assemblages featuring mixed elements of the Tisza and Vinča material cultures. This is, for example, the case not only for Gradište-Iđjoš, but also other sites in the region, such as Kremenjak-Čoka, Matejski Brod, Bajir, Akača-Novo Miloševo, Crna Bara and Kamara Humka, which occupy an area close to the course of the Tisza between central Banat (Aranka/Zlatica and Jegrička rivers), and the present-day border between Serbia and Hungary (Brukner 1968: 77). Therefore, the study of these sites offers the opportunity to explore the nature of potential intercultural interaction between the producers of the Vinča and Tisza material cultures as is visible in the archaeological record.

Potporanj is situated in south-eastern Serbian Banat, an area marked by the Vršac mountain range and loess flats over which the site lies. During the Neolithic, the settlement was surrounded by marsh from its three sides, forming a peninsula-like area with an entrance to the southeast. Potporanj, with an estimated size of 100 hectares and $3.5 \mathrm{~m}$ of cultural layer, is the largest Neolithic site of this area (Chapman 1981). Previous (Brukner 1960; Milleker 1934; 1938) and on-going excavations at the site (Pantović 2013) uncovered Starčevo and early Vinča pottery and the largest quantity of obsidian found within the Vinča network (Marić 2015). Provenance studies of this material indicate that obsidian used at Potporanj originated in the Hungarian and Slovakian Carpathian Mountains (Tripković and Milić 2008). Recent radiocarbon dates (Whittle et al. 2016) demonstrate that the site had a short lifespan of not more than 300 years (5312-5221 cal. BC to 5213-5019 cal. BC) covering the earliest phase of the Vinča phenomenon (A-C; Tordoš I-Gradac). However, the reasons for the abandonment of the site remain unclear. Due to its association with the early Vinča phases, Potporanj represents earlier traditions of pottery production in the southern Serbian Banat.

Belovode is located in central Serbia on a plateau located near to the village of Veliko Laole, $10 \mathrm{~km}$ to the southwest of Petrovac on the Mlava river. Archaeological excavations at Belovode beginning in 1993 revealed a cultural layer up to $4 \mathrm{~m}$ in the centre of the settlement that covers the complete sequence of the Vinča phenomenon from Vinča Tordoš to the Gradac phase (Radivojević et al. forthcoming; Šljivar and Jacanović 1996a; 1996b; 1997). 
Occasional finds of Starčevo pottery indicate a possible occupation by this cultural phenomenon that began during the 6th millennium BC. This site has yielded the earliest known evidence for copper smelting in the world, dated at around 5000 BC (Radivojević et al. 2010). Therefore, the occupational sequence and the presence of early smelted copper renders Belovode an important site for studying the emergence of the European Chalcolithic.

The site of Pločnik lies in Southern Serbia near its eponymous village on a fertile floodplain. The area is surrounded by springs and small flows on the left bank of the Toplica River, which originates from the Kopaonik mountain range, c. $50 \mathrm{~km}$ away. The site was first identified with the discovery of metal artefacts during the construction of the Yugoslav railway in 1926. The first archaeological campaigns were conducted in 1928, leading to the discovery of further copper implements (Grbic 1929). Since then, the settlement has been the subject of continuous national and international interest (Radivojević et al. forthcoming; Šljivar and Kuzmanović-Cvetković 1997; 1998; Stalio 1962) revealing a cultural layer that represents the sequence of the Vinča phenomenon from the earliest observable phase to its very end (Vinča-Tordos Ia/ Vinča A2- Gradac III). Pločnik yielded the world's earliest known tin-bronze object, dated to approximately 4650 BC (Radivojević et al. 2013; Radivojević and Kuzmanović-Cvetković 2014). Furthermore, the sequence from Pločnik was used by later scholars to construct the final development of late Vinča phenomenon (Jovanović 1993/1994). In this study, Jovanović proposed a division of the Gradac phase in 3 sub-phases defined as Gradac I, II and III with the latter attested only in the Morava valley and its tributaries in central and south Serbia. The start of this phase is placed at the beginning of the 5th millennium BC, the end varies between c. 4600 and c. $4400 \mathrm{BC}$ (see Radivojević and Grujić 2018; Radivojević et al. forthcoming).

\section{Materials and Methods}

\subsection{Ceramic petrography and paste recipes}

Samples in this study were selected to maximise the representation of each Vinča chronological phase, but also the typological and technological variability observed during their macroscopic examination. Therefore, the specimens for ceramic petrography were chosen so that they could represent different functional vessels groups, decoration styles and 
macro-fabrics (complete list of samples and their description is provided in the supplementary materials).

The archaeometric method applied here consists of the description, classification, and interpretation of ceramic pastes or fabrics in thin section, adopting techniques deriving from those used in geology and soil micromorphology to describe rocks (Quinn 2013; Whitbread 1995). Patterns in the nature and arrangements of various elements visible in thin section provide insights into the process of clay paste preparation. Variability in the mineral composition of ceramic raw materials helps to define the natural resources employed in the production process, therefore providing important information regarding the selection and processing of raw materials and artefacts provenance. Ethnographic studies (Arnold 2017) indicate that potters select raw materials based on a range of factors, some of which are technical or practical such as material properties, location, accessibility, ease of transportation, and the ownership of land and resources. However, the selection of natural resources for pottery production can also be influenced by rituals and taboos. As petrography allows for the provenance of raw materials, it helps the reconstruction of landscape use and, with further study, can reveal related economic and social behaviours.

In our study, the distinction between the use of primary and secondary clay deposits is particularly important for the identification of ancient raw materials sources (Quinn 2013: 120). Primary or residual clay forms in situ. These are smaller deposits and are situated close to the parent rock from which they derive. Secondary or 'sedimentary' clay sources originate from the erosion, transportation and deposition of clay rich material by water. Distinguishing between primary and secondary clays in archaeological ceramics can be somewhat difficult, but clay sources can be identified based on specific textural and compositional characteristics observed in thin section (Quinn 2013: 121).

Upon collection, natural clays are processed through crushing and cleaning (e.g. sieving or levigation) or altered by the addition of aplastic materials (tempers) and clay mixing (Quinn 2013: 154-171). Particular attention in our study has been given to the study of tempers as they affect several physical characteristics of the fired ceramic including permeability, heating effectiveness, thermal shock resistance and toughness (Tite et al. 2001). They can also affect the general visual appearance of pottery, for example mica inclusions reflect light and give vessel surfaces a pleasant shiny effect. Ethnographic research shows that the selection of one type of temper over another is not always influenced by a desire to optimise ceramic function, but for other cultural purposes (e.g. Arnold 2017; Carlton 2019) as well. 
Tempers can be recognised based on their composition, as they do not normally occur in natural clay deposits (e.g. bone, plant matter, grog and slag). Another important parameter is the grain size-distribution. For example, sediments with a clear bimodal distribution are not common in nature, and therefore the presence of this pattern indicates the use of temper (Quinn 2013: 156-171).

Though our study focuses on paste recipes, other elements of pottery technology are taken into account. Forming techniques are considered to be a useful proxy for ceramic traditions as they are the most conservative trait in ceramic technology (Roux 2017). However, a detailed study of ceramic forming techniques in Vinča sites is very limited and are challenged by the high fragmentation that characterises these pottery assemblages (Vuković 2011: 83). In addition, most studies (Figure 1) focused on Vinča ceramic manufacturing include a characterisation of the paste composition. Therefore, there are enough data on this specific aspect of pottery production to reconstruct ceramic manufacturing traditions at a supraregional level.

\subsection{The archaeological and geological samples}

The ceramic samples from Belovode and Pločnik together cover the entire sequence of the Vinča material culture and represent the largest of the assemblages studied as they were analysed as part of a doctoral research project (Amicone 2017). The results of the analysis carried out in Gradište-Iđjoš and Potporanj are instead the outcome of pilot projects carried out as part of on-going studies of the ceramic assemblages found at these two sites. The materials from Gradište-Iđjoš are from the older excavations (1954 and 1972) and represent the last phase of the settlement that is marked by mixed Vinča and Tisza style assemblages (Vinča C, c. 5000-4800 BC). Samples from Potporanj come from the new on-going excavations and cover the entire lifespan of the site (Vinča Tordoš I-Gradac / Vinča A-C).

Another important step of this study focuses on the knowledge of the available sources of raw materials for pottery making that are found near the sites. This was achieved combining the study of geological maps (supplementary materials) and literature (e.g. Dimitrijević 1997) with raw materials prospecting (without employment of coring) around three of the four sites (Belovode, Pločnik, and Gradište-Iđjoš). A selection of samples collected during surveys was analysed through thin-section petrography and the results were compared to those retrieved from the study of the ceramic samples in order to identify and characterise local productions 
of the studied sites (Quinn 2013: 131-137). The location of the geological samples presented in this study together with the overall position of all the samples collected during the geological prospections is indicated in the geological maps (supplementary materials).

Only ceramic petrographic fabrics that were recognised as local productions are presented in this paper. Local productions were identified by assessing the representation of each fabric at its respective site and the correspondence of raw materials with the local geology. The overall results are compared to petrographic studies of other Vinča sites that were subject of similar studies (e.g. Kaiser 1984, 1989; 1990; Kreiter et al. 2011; Spataro 2014; 2018), but also with the wider Balkans area (e.g. Kreiter et al. 2009; 2017a; 2017b; 2019; Spataro 2017; Szakmány et al. 2019). The materials studied by Kaiser were made accessible to the leading author (S. Amicone) of this paper for the purposes of conducting this study.

\section{Results}

\subsection{Result of the ceramic petrographic analysis}

\section{Gradište-Iđjoš}

The 22 samples from Gradište-Iđjoš analysed (Vinča C, c. 5000-4800 BC) showed the presence of three local fabric groups (Mirković-Marić and Amicone 2019).

Fine fabric ID-A (Figure 3: a-b) includes 10 samples, marked by the presence of subangular quartz fragments. Plagioclase and muscovite are common, amphibole and calcite are rare. The grain size distribution is unimodal. The matrix is non-calcareous and ranges from dark grey to pale brown in XP and light grey to light yellow in PPL. Samples ID 12, ID 19 are slightly coarser (average grain size $0.12 \mathrm{~mm}$ ). This fabric is characteristic of darkburnished Vinča bowls but could be found also in association with a hybrid bowl and Tisza bowl. 

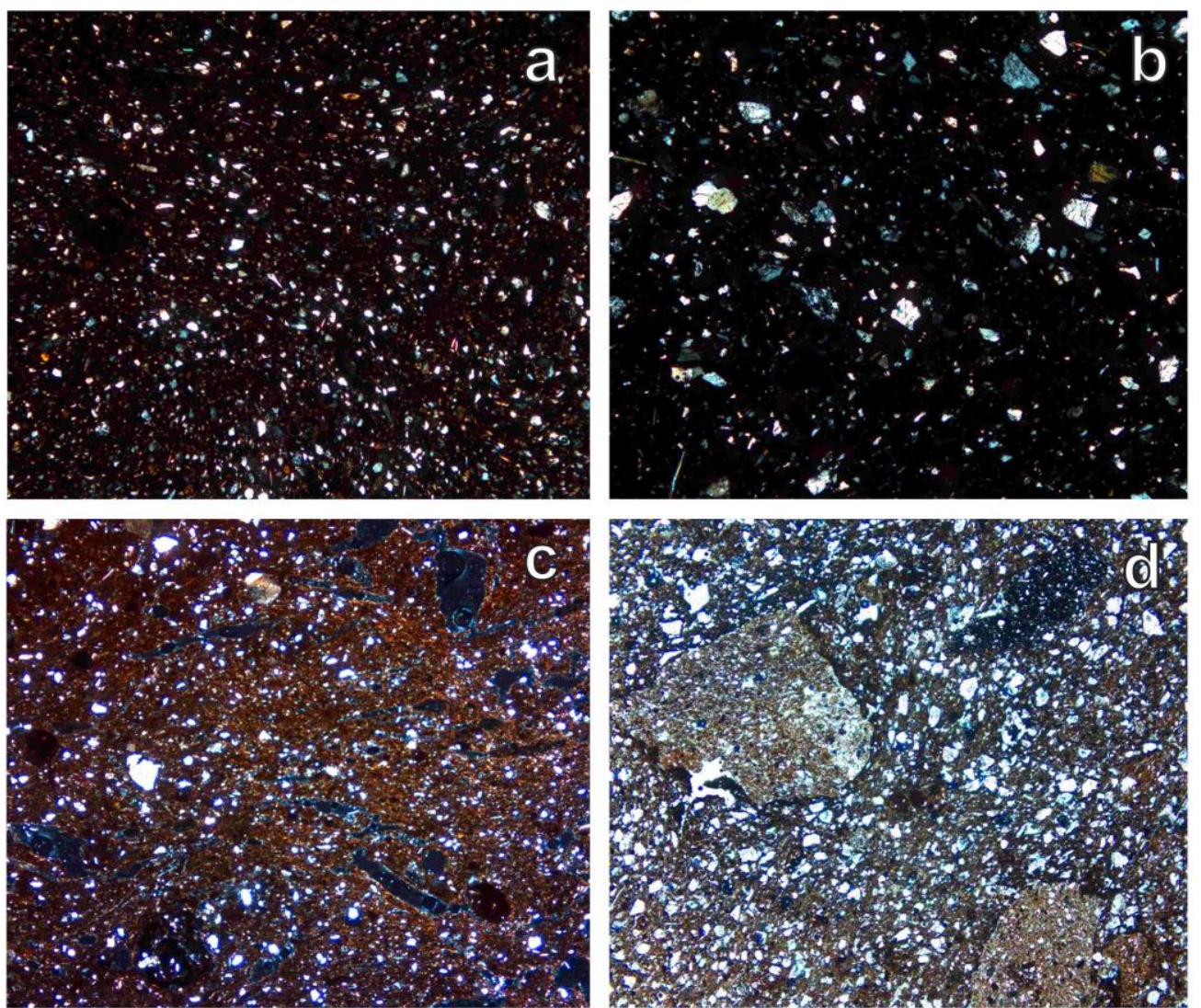

Figure 3: Thin section photomicrographs of selected ceramic from Gradište-Iđoš: a) Fabric ID-A (ID 4) very fine, XP); b) Fabric ID-A, coarser (ID 2), XP; c) Fabric ID-B (ID 10) with plant tempering, XP); d) Fabric ID-C (ID 13) fabric 3 with grog tempering. Image width $=3$ $\mathrm{mm}(\mathrm{a}, \mathrm{b})$ and $6 \mathrm{~mm}(\mathrm{c}, \mathrm{d})$.

Plant-tempered fabric ID-B (Figure 3: c) comprises 4 samples and it is marked by plant tempering, as suggested by the presence of planar voids often showing carbonised organic material. The dominant type of inclusion is sub-angular quartz. Plagioclase and muscovite are common, amphibole and calcite are rare. Grain size distribution is polymodal. The matrix is non-calcareous bright orange in XP and light orange in PPL. This fabric occurs on unburnished Vinča amphora and Tisza lids decorated with incisions.

Grog fabric ID-C (Figure 3: d) includes 8 specimens and it is characterised by the use of fine quartz sand and abundant grog as a temper. The dominant type of inclusion is sub-angular quartz. Plagioclase and muscovite are common, whereas amphibole and calcite are rare. Grain size distribution is bimodal. The matrix is a non-calcareous bright orange in XP and light orange in PPL. The fabric is typical for Tisza medium-coarse vessels (conical lid) and cooking vessels (pots and pans). 
The mineral inclusions and textural characteristics indicate that these fabrics were produced using a secondary sandy-clay source that was processed in various ways to produce the above described pottery pastes.

Potporanj

Five potential local fabrics among the 28 samples analysed in Potporanj have been recognised.

Metamorphic-plutonic fabric POT-A (Figure 4: a-c, 11 samples) features specimens marked by sub-angular metamorphic rock fragments composed of quartz and muscovite added as temper (possibly gneiss) and plutonic rock fragments (probably granite) and could be divided in two subgroups (POT-A1, 8 samples - POT-A2, 3 samples). The salient difference between them appears in the grain size distribution. POT-A1 is poorly sorted while POT-A2 is well sorted and strongly bimodal. Other common to frequent inclusions are chert, quartz, feldspars and muscovite. The matrix is non-calcareous pale brown to dark brown in colour in XP and PPL. Cooking pots appear to be especially associated with this fabric, that seems to be attested in all the Vinča phases of this site.

Fine fabric POT-B (Figure 4: d, 4 samples) is a fine fabric in which sub-angular quartz represents the dominant inclusion, while muscovite and plagioclases are frequent. Small fragments of metamorphic rocks are also present. The grain-size distribution is polymodal. The matrix in these samples is non-calcareous reddish brown to dark brown in XP and light brown to dark grey in PPL.

Very fine fabric POT-C (Figure 4: e, 7 samples) is marked by frequent sub-angular quartz and few muscovite and plagioclase inclusions. Grain size distribution is unimodal. The matrix is a non-calcareous light brown to very dark brown in XP and light brown to dark brown in PPL. Fabrics POT-B and POT-C seem to be especially associated with dark burnished vessels. Calcareous fabric POT-D (Figure 4: f, 6 samples) is marked by the presence of shells and microfossils, where the dominant mineral inclusion is quartz, calcite is common and with some plagioclase and biotite inclusions. The grain-size distribution is polymodal. The matrix is calcareous light brown to very dark brown in XP and brown to dark brown in PPL. This fabric seems to be attested only in the Vinča A phase of this settlement. 

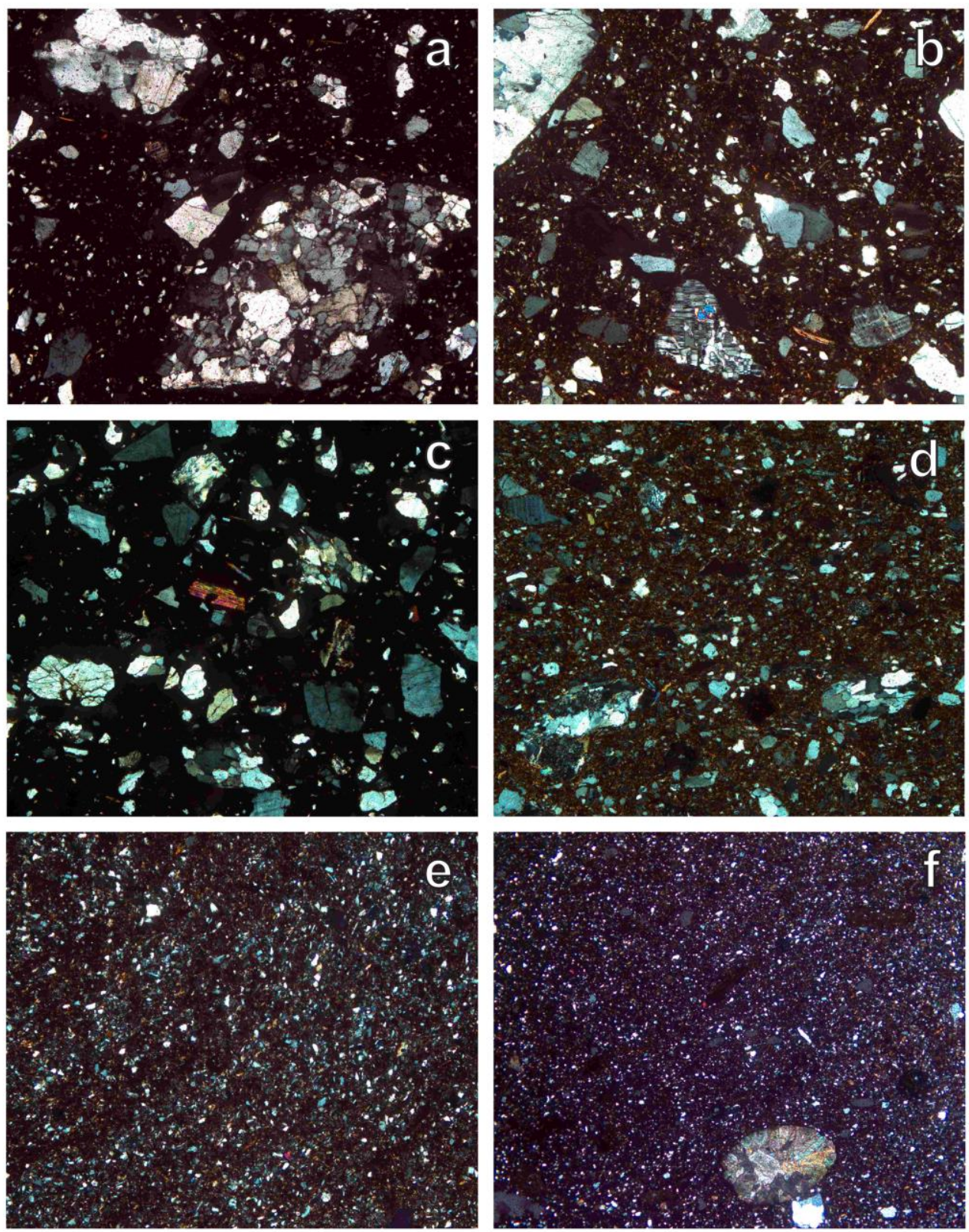

Figure 4: Thin section photomicrographs of selected ceramics from Potporanj analysed in this study: a) Fabric POT-A1 (POT 3), with fragments of metamorphic rocks, XP; b) Fabric POTA1 (POT 23), with quartz, microcline and perthite, XP; c) Fabric POT-A2 (POT 1), with quartz and fragments of metamorphic rocks, XP; d) Fabric POT-B (POT 9), small fragment of metamorphic rocks, XP; e) Fabric POT-C (POT 6), very fine, XP; f) Fabric POT-D (POT 7), calcareous clay with microfossils, XP. Image width $=3 \mathrm{~mm}(\mathrm{a}, \mathrm{b}, \mathrm{d}, \mathrm{e})$ and $6 \mathrm{~mm}(\mathrm{c}, \mathrm{f})$.

The compositional and textural characteristics of these fabrics could indicate that the raw materials used to produce fabrics POT-A, POT-B and POT-C at Potporanj could have been a loessic clay source that was processed via cleaning and then tempering to produce the 
different pastes described above. Conversely, the clay used to produce fabric POT-D could have been a calcareous sedimentary source rich in microfossils.

Belovode

Among the samples analysed in Belovode, two potentially local fabrics have been recognised (Amicone 2017: 154-160).
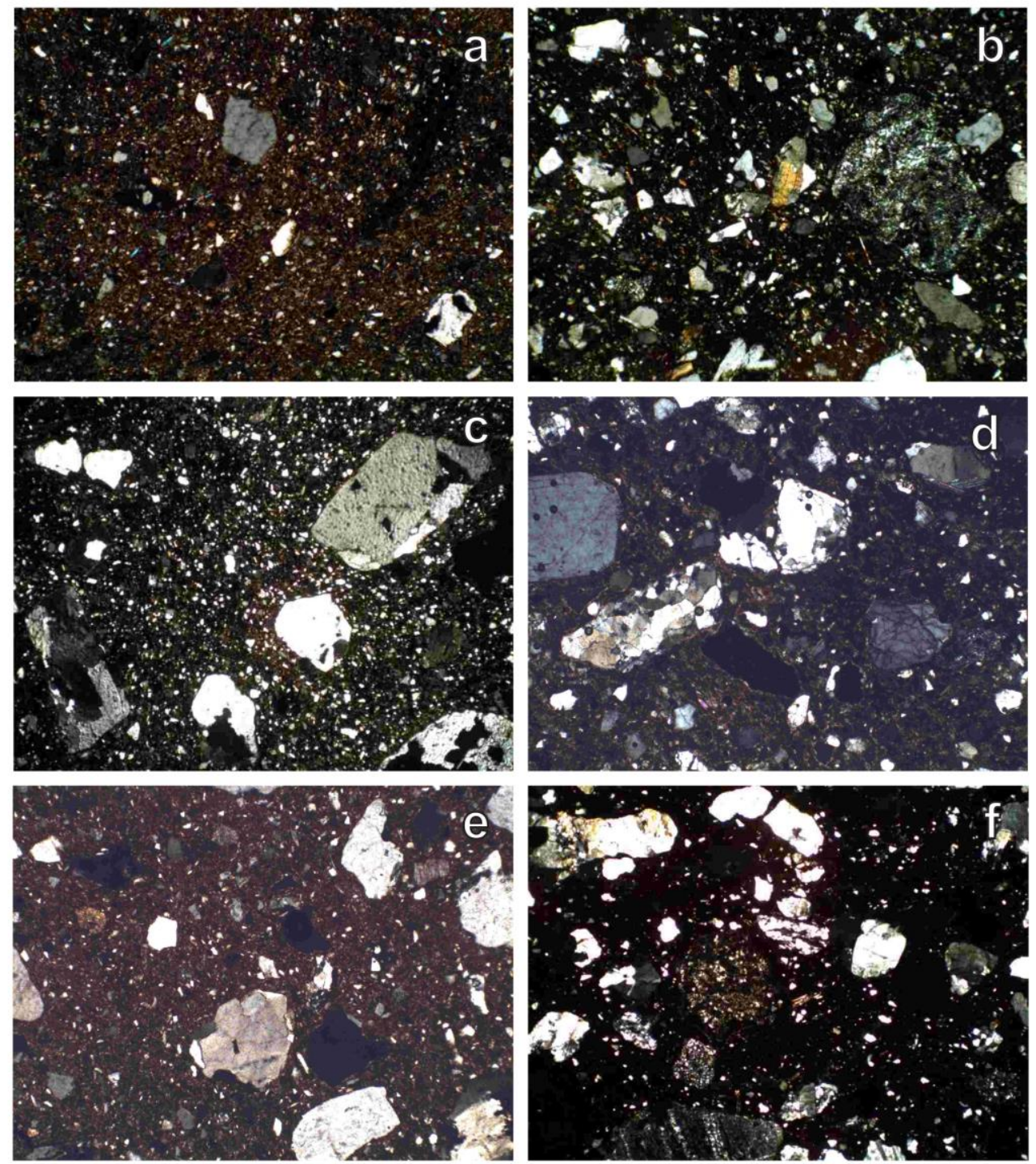

Figure 5: Thin section photomicrographs of selected ceramics from Belovode analysed in this study: a) Fabric BEL-A2 (BEL 18-198), fine with abundant quartz, plagioclase and fragments of metasedimentary rocks, XP; b) Fabric BEL-A1 (BEL 18-2), coarse, XP; c) Fabric BEL-A1 (BEL 18-310), bimodal distribution, XP; d) Fabric BEL-A1 (BEL 18-193), bimodal distribution, XP; e) Fabric BEL-A1 (BEL 18-275), bimodal distribution, XP; f) Fabric BELA1 (BEL 18-10), bimodal distribution, XP. Image width $=3 \mathrm{~mm}(\mathrm{a}, \mathrm{b}, \mathrm{d}, \mathrm{e})$ and $6 \mathrm{~mm}$ (c, f). 
Metasedimentary rock fabric (fabric BEL-A) comprising 105 specimens. Samples assigned to this fabric form a heterogeneous coarse (sub-fabric BEL-A1, 58 samples) to fine-grained (sub-fabric BEL-A2, 47 samples) group (Figure 5 and 6).

This fabric is characterised by generally poorly sorted sub-angular to sub-rounded inclusions of quartz, polycrystalline quartz, plagioclase and k-feldspars. The dominant mineral inclusions are quartz and plagioclase. Muscovite, chert, opaque minerals, and clay pellets are common, with some inclusions of epidote and amphibole and rare calcite and mudstone.

In the coarser-grained specimens, the common presence of fragments of low-grade, nonfoliated metamorphic rocks composed of quartz are observed. This composition is indicative of metasedimentary rocks, more specifically meta-arenite. The grain size distribution is generally polymodal to weakly bimodal.

The matrix is non-calcareous, and the colour varies from light yellow and bright orange to dark red in PPL. In XP, colours range from light brown and dark reddish to grey. Based on these mineral inclusions and textural characteristics, the raw materials used to produce these ceramics could have been a secondary sandy-clay source. However, significant compositional and textural variation has been noted in this group, which can be subdivided into several smaller groups. Seven samples (Figure 5: c-e) show a slightly bimodal distribution of the mineral inclusions that could be evidence for tempering. Six specimens exhibit proof for the possible addition of aplastic material as well too but do also show some textural and minor compositional variability.

More precisely, two specimens (Figure 5: f) are coarse-grained (average inclusions size 1.5 $\mathrm{mm}$ ) with a high abundance of well-sorted rock fragments of metasedimentary rocks, chert and microcline. Two other samples (Figure 6: a) show possible evidence for the addition of mudstone, whereas one specimen (Figure 6: b) is characterised by the presence of plant material, but it is not clear if this is naturally occurring or added as temper. In addition, four specimens (Figure 6: c) contain limestone fragments that were possibly added as temper. Finally, one sample (Figure 6: d) stands out for the notably higher quantity of clay pellets and chert within the ceramic matrix. This fabric is found in all the Vinča phases attested in this settlement and in association to a variety of morphological and decorative types. It could have been produced from a sedimentary sandy-clay source marked by considerable variability. 

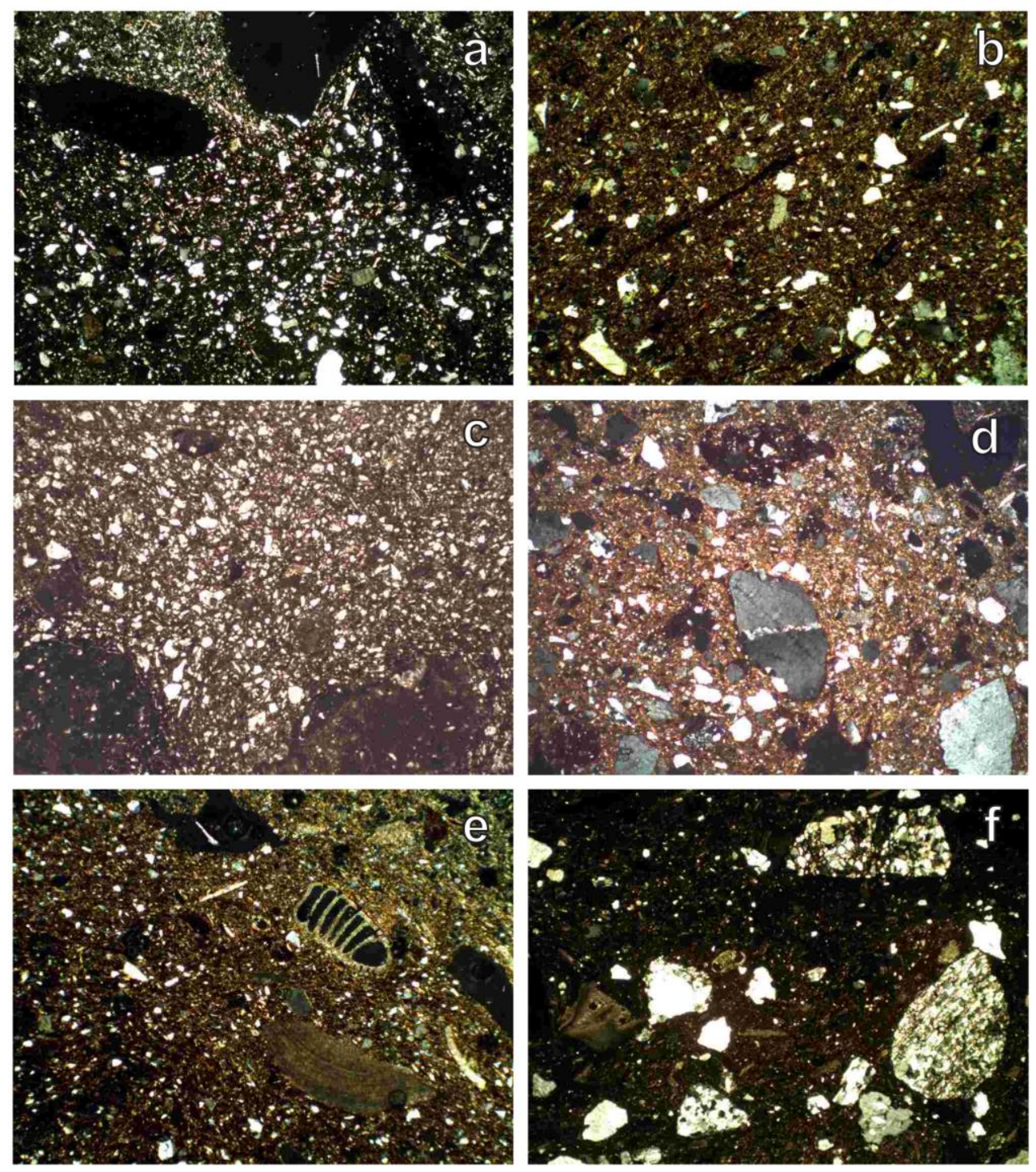

Figure 6: Thin section photomicrographs of selected ceramics from Belovode analysed in this study: a) Fabric BEL-A1 (BEL 18-67) with mudstone, XP; b) Fabric BEL-A2 (BEL 18-104) with few organic inclusions, XP; c) Fabric BEL-A1 (BEL 18-300), with limestone, PPL; d) Fabric BEL-A1 (BEL 18-318), abundant clay pellets, XP; e) Fabric BEL-B2 (BEL 18-280) with shells and microfossils, XP; f) Fabric BEL-B1 (BEL 18-96) with shells, microfossils and metasedimentary rocks, XP. Image width $=6 \mathrm{~mm}(\mathrm{a}, \mathrm{c}, \mathrm{d}, \mathrm{f})$ and $3 \mathrm{~mm}(\mathrm{~b}, \mathrm{e})$.

Fossiliferous fabric (fabric BEL-B). Samples of this fabric (23 specimens) compose a heterogeneous coarse (sub-fabric BEL-B1, 16 samples)-to-fine-grained (sub-fabric BEL-B2, 7 samples) group (Figure 6: e, f) marked by the presence of shell fragments, microfossils and poorly-sorted sub-angular to sub-rounded inclusions of quartz. Dominant mineral inclusions are composed of the previously mentioned quartz and polycrystalline quartz. Shell fragments frequently occur, and plagioclase, muscovite, calcite, opaque minerals, chert and clay pellets are also common. However, epidote and amphibole are only rarely present. In the coarser 
samples, it was possible to observe few fragments of meta-sedimentary rocks and mudstone. The grain size distribution in these samples is generally polymodal. The colour is light yellow in PPL and yellow-to-dark brown in XP. Most samples feature a non-calcareous matrix. Based on the compositional and textural characteristics described above, the raw material used to produce these ceramics seems to be formed from a natural mixture of a sandy-clay source and fragments of weathered limestone. This fabric seems to be especially associated with cooking pots and started to appear from the Gradac phase.

Pločnik

The samples analysed from Pločnik contain two local fabric groups. (Amicone 2017: 192198). Sedimentary rock fabric (fabric PL-A), comprising 175 samples, clearly represents the predominant paste at Pločnik (Figure 7: a-f). Samples assigned to this fabric form a heterogeneous coarse group (sub-fabric PL-A1, 95 samples), as well as a finer-grained group (sub-fabric PL-A2, 80 samples). The fabric is marked by generally poorly sorted, sub-angular to sub-rounded inclusions of quartz and plagioclase that seem to derive from quartz-arenite or arkosic-arenite sandstones. Quartz and plagioclase represent dominant inclusions, while fragments of sandstone rocks occur frequently. Other common inclusions are muscovite, amphibole, perthitic feldspar, microcline, chert, opaque minerals and clay pellets. Calcite and biotite are rare. A small number of samples contain a few fragments of meta-sedimentary rocks as well. The grain-size distribution of these samples ranges from polymodal to weakly bimodal. Some samples from horizons 5 and 4 show a stronger bimodality (possible evidence of tempering). The matrix is non-calcareous and ranges from light yellow, bright orange to dark red in PPL, and from light brown, dark reddish to grey in XP. The compositional and textural characteristics seem to suggest that the raw material used for this fabric was a primary clay containing sedimentary rock clasts and characterised by significant variability. Samples associated to this fabric cover the entire lifespan of this settlements and all the different morphological and decorative types uncovered at Pločnik.

The micaschist rock fabric (fabric PL-B) features 25 samples. It is a coarse-to-mediumcoarse-grained fabric characterised by the presence of generally well-sorted, angular to subangular inclusions of quartz and metamorphic rock fragments (Figure 7: g, h). Quartz and muscovite comprise the dominant inclusions. Plagioclase, K-feldspar, biotite, opaque minerals and clay pellets occur frequently. 

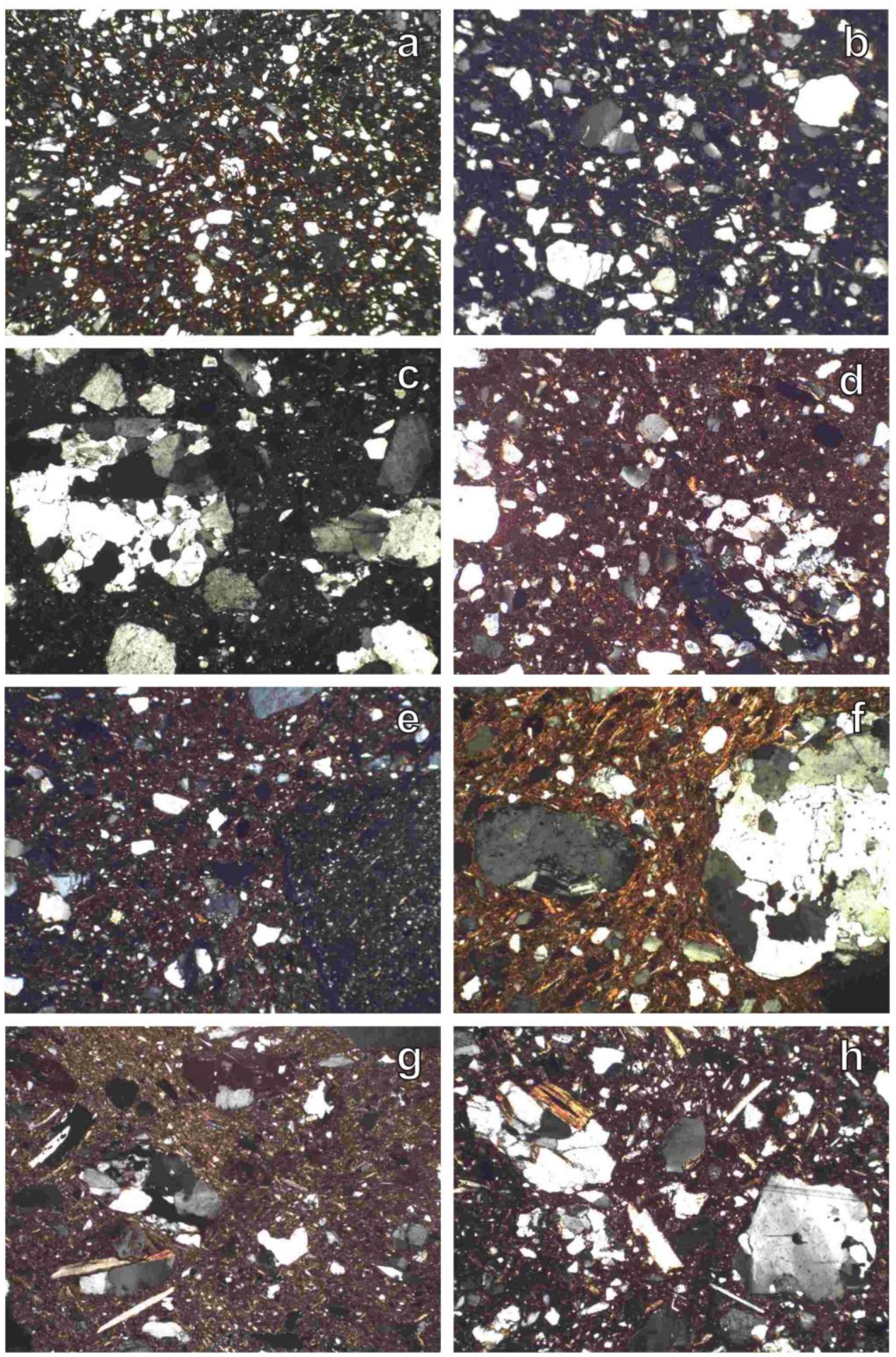

Figure 7: Thin section photomicrographs of petrographic fabrics from Pločnik: a) Fabric PLA2 (PL 24-69) with sedimentary rocks (fine), XP; b) Fabric PL-A2 (PL 24-219) with sedimentary rocks (medium-fine), XP; c) Fabric PL-A1 (PL 24-132) with sedimentary rocks (coarse), XP; d) Fabric PL-A1 (PL 20-78) with arkosic arenite, XP; e) Fabric PL-A1 (PL 2153) with siltstone, XP; f) Fabric PL-A1 (PL 24-306) with sedimentary rocks and abundant muscovite, XP; g) Fabric PL-B (PL 21-19) with micaschist, XP; h) Fabric PL-B (PL 24-54) with micaschist, XP. Image width $=3 \mathrm{~mm}$. 
Foliated high-grade metamorphic rock fragments rich in quartz and muscovite are common (probably mica-schist). Fragments of phyllite, meta-sedimentary rocks and epidote are rare. The grain-size distribution in many samples assigned to this fabric is strongly bimodal and therefore suggests tempering. The matrix is non-calcareous and its colour ranges from light brown, and bright yellow to light orange in PPL and from light brown to reddish yellow in $\mathrm{XP}$. The matrix is quite homogeneous, save for the core-margin colour differentiation caused by the firing process. Based upon these mineral inclusions and textural characteristics, the clay used to produce these samples seems to be a secondary clay into which mica-schist has been added as temper. This fabric is particularly attested in the last phase of this settlement (Gradac II and III) on non-burnished/polished vessels.

\subsection{Raw materials for pottery making}

\section{Gradište-Iđjoš}

The geology of the north-centre Serbian Banat (location of Gradište-Iđjoš) is characterised by several Pleistocene and Holocene alluvial sediments marked by the presence of gravel, sand and clay (Koprivica and Strajin 1994). Near Gradište-Iđjoš, samples of alluvial sediments were selected to study the nature and distribution of gravel, sand and clay. Geological references come from two main locations (see Geological map of Gradište-Iđjoš in the supplementary materials).
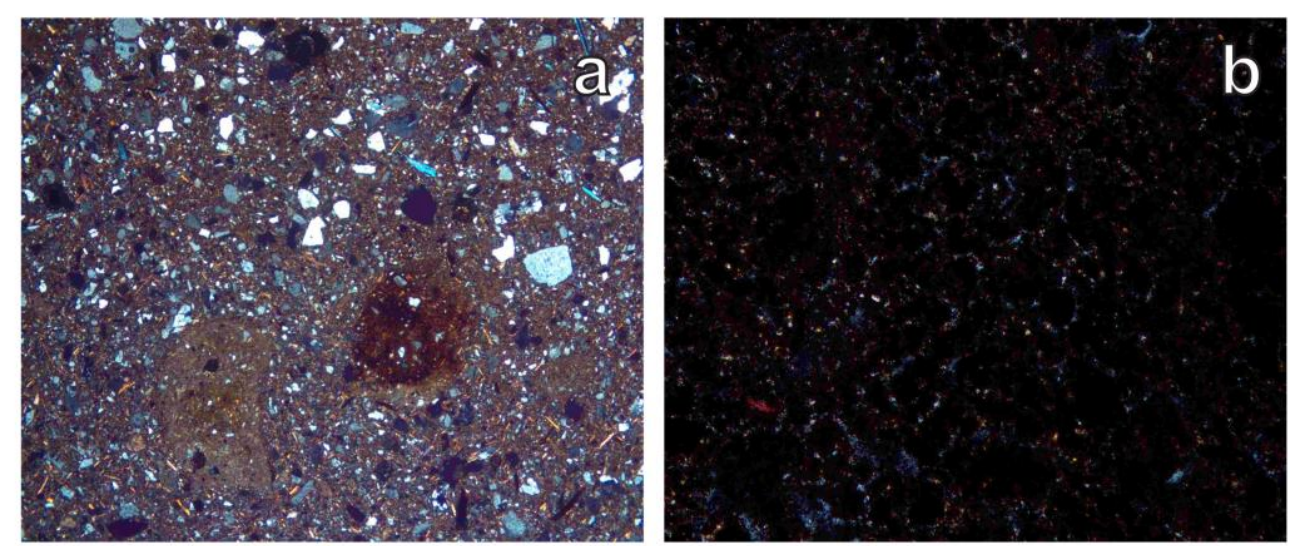

Figure 8: Thin section photomicrographs of selected geological samples around GradišteIđjoš: a) Clay from Mokrin (point 2), XP; b) Very fine clay from Gradište-Iđjoš (point 1). Image width $=6 \mathrm{~mm}$ (a) and $3 \mathrm{~mm}(\mathrm{~b})$. 
One of the selected areas for geological reference samples lies close by the archaeological settlement and another clay source is c. 10km away from Gradište-Iđjoš near Mokrin. The latter site contains sediments of Pleistocene origin with outcrops of clay that continue to be exploited by the modern brick industry. The clay in Mokrin appears sandier and is marked by the occurrence of quartz, feldspars, muscovite and minor quantity of calcite and rarely metamorphic rocks (Figure 8: a). The clay collected from the Gradište-Iđjoš clay source is very fine and marked by the occurrence of fine quartz and muscovite (Figure 8: b).

\section{Potporanj}

Potporanj is located on an alluvial plain and its surroundings appear to be characterised by the presence of loess, loessic and uliginous clay sources (Vuković et al. 1970). The mountain situated in the vicinity of Vršac features a granitic formation and migmatites. The latter is a composite rock found in medium and high-grade metamorphic environments. It consists of two, or more constituents often layered repetitively; one layer was formerly paleosome, a metamorphic rock (in this case gneiss) that was reconstituted subsequently by partial melting; the alternate layer has a generally plutonic appearance (e.g. granite).

\section{Belovode}

The area of the site of Belovode is covered by Neogene deposits and projects outwards over the Triassic area of the Carpatho Balkanides to the east (Vujisić et al. 1977). It is characterised by metapsammites and metadiabases of the greenschist facies group. These rocks form a continuous horizon of quartzite which is underlined by acidic metavolcanics, metapelite and metapsammite. This $800 \mathrm{~m}$ thick succession is covered by metaconglomerate and metagreywacke, intruded by gabbro of the Kupinovačka Glavica. Belovode itself is situated on a Neogene formation which lies over the older base of conglomerate, sandstone, mudstone and sandy limestone. Superficial and recent deposits include alluvial sand and clay of the nearby Busur River. A total of 32 specimens of clay and rocks from 29 different locations were collected during the geological prospections (see Belovode geological map in supplementary materials), but only those sampled within the closer vicinity of the site are discussed here. Samples of Neogene sandy-clay collected in proximity to Belovode (Figure 9: a-d) show the presence of quartz, opaque minerals and metasedimentary rocks. There are 
also few inclusions of amphibole and epidote. Neogene limestone was sampled near the site and is shown to have a shelly oolitic composition (Figure 9: e). This limestone weathered to a sandy-clay marked by shells, microfossils and calcite that was sampled in the same area (Fig. 9: f).
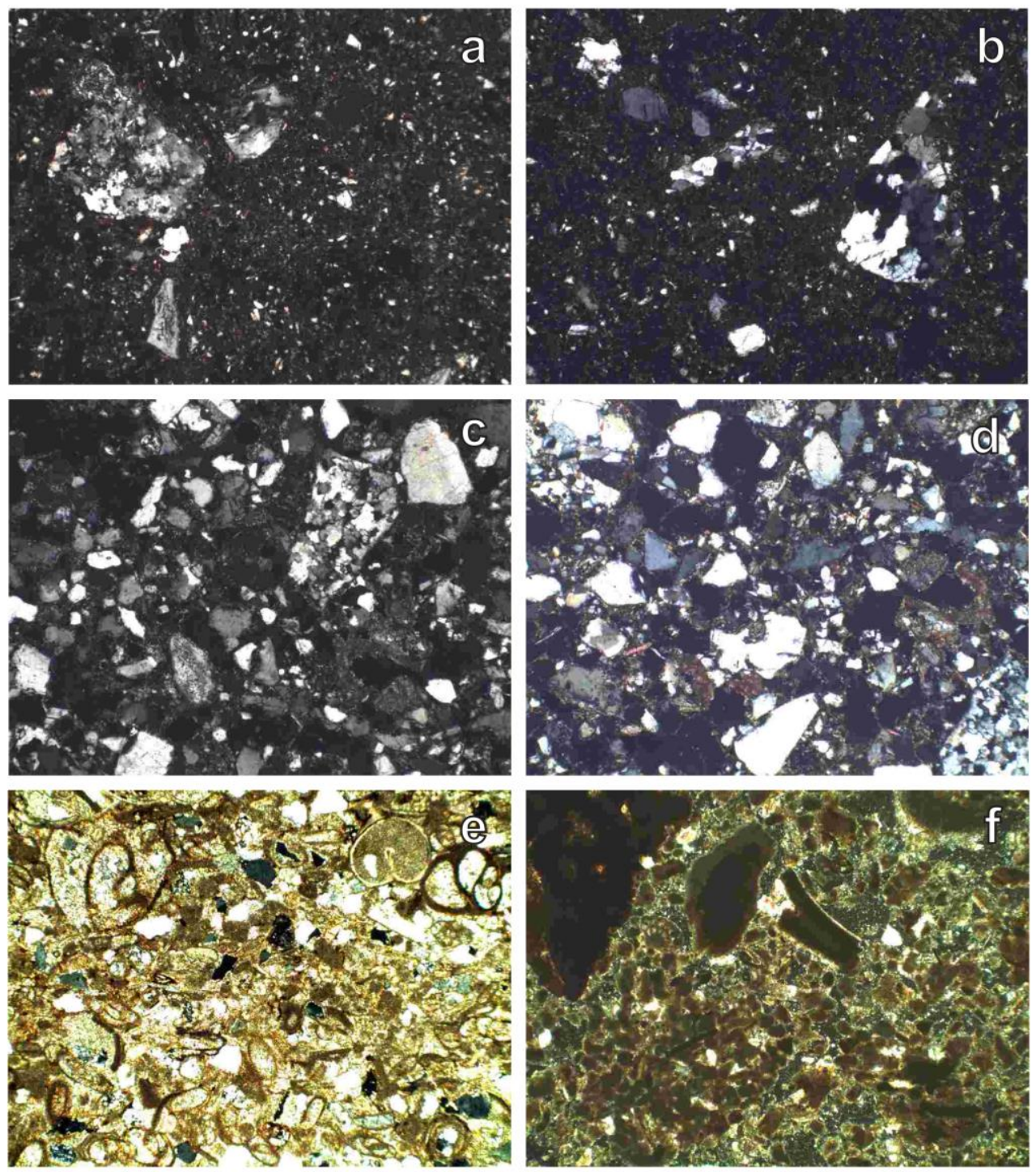

Figure 9: Thin section photomicrographs of selected geological samples from Belovode: a) Sandy-clay (Point 2, Sample 3), XP; b) Sandy-clay (Point 12, Sample 13), XP; c) Sandy-clay (Point 14, Sample 15), XP; d) Sand (Point 24 Sample 26), XP; e) Shelly-limestone (Point 1, sample 2), XP; f) Sand (Point 1, sample 1), XP. Image width $=3 \mathrm{~mm}$. 
Pločnik

Pločnik is situated on top of an alluvial quaternary deposit related to the Toplica River around which there are Cretaceous deposits of flysch, sandstone, marl, and olistostrome, covering the Precambrian formations constituted by leptinolite and mica-schist, fine-grained biotite and gneiss, as well as amphibolite, which outcrops east of the site in the area of Prokuplje (Malešević et al. 1980).
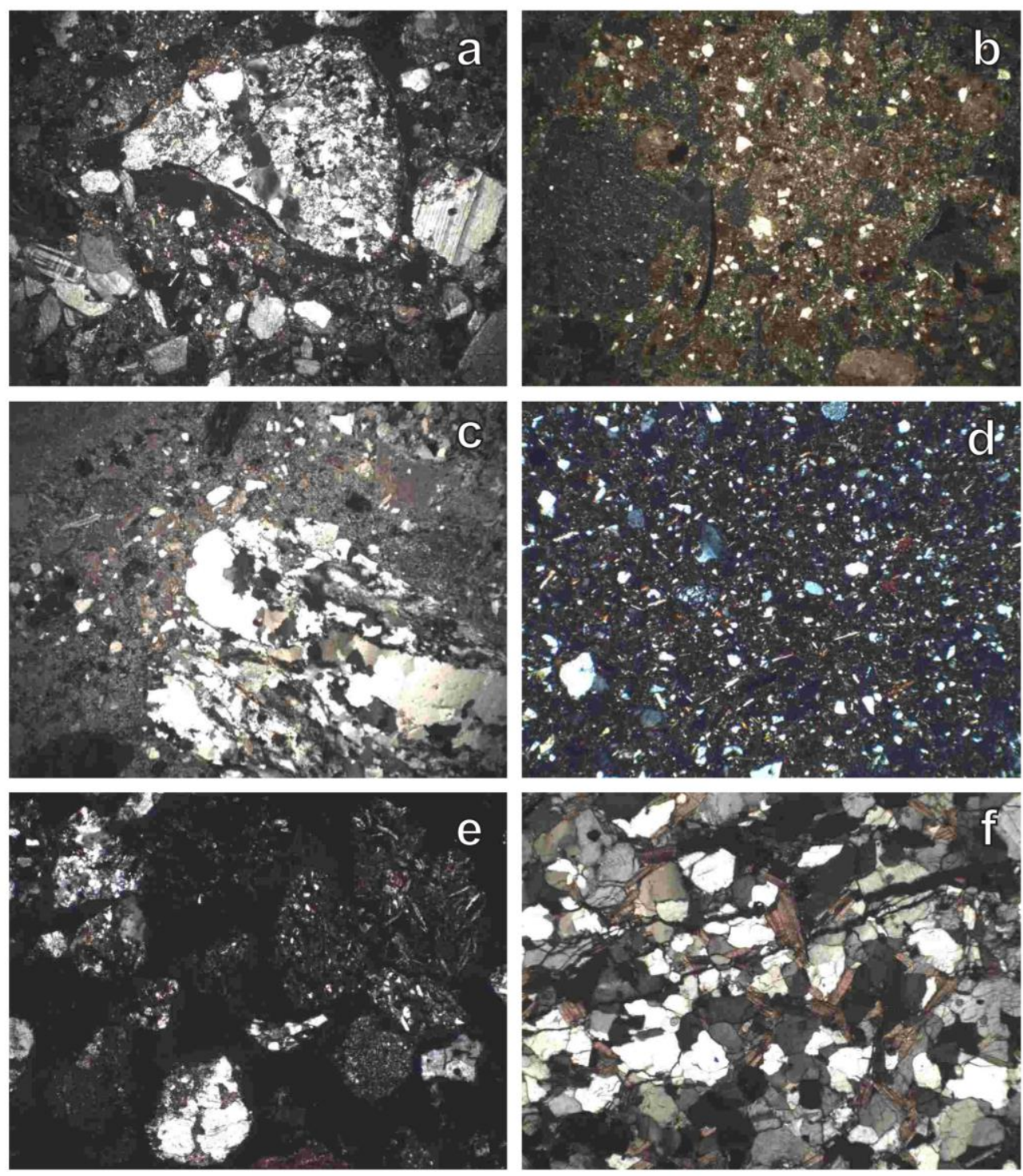

Figure 10: Thin section photomicrographs of selected geological samples from Pločnik: a) Sandy-clay (point 40, sample 46, near Pepeljevac ), XP; b) Clay (point 35, sample 38, near Pločnik), XP; c) Marl and sand (point 4, sample 5, close to Pločnik ), XP; d) Sandy-clay from Viča, XP; e) Sand from Toplica River, XP; f) Fragment of mica-schist (point 8, sample 10), XP. Image width $=6 \mathrm{~mm}$ (a, b, c, d), $3 \mathrm{~mm}$ (f) and 1,5 $\mathrm{mm}(\mathrm{e})$. 
The formations described above are partially cut through by the Quaternary alluvial valley of the Toplica River and its tributaries. A total of 49 specimens of clay and rocks from 41 different locations were samples during the geological prospections (see Pločnik geological map in supplementary materials), but, as with Belovode, only those collected within the closer vicinity of the site are discussed here. Samples from the Cretaceous formations collected around Pločnik show that these formations are marked by clay and sandy-clay sources that contain quartz and various types of sedimentary rocks (Figure 10: a, b). Sedimentary rocks recovered from the Cretaceous formations include quartz arenite, arkosic arenite, lithic arenite and siltstone. These formations also contain layers of calcareous clay, probably marl (Figure 10: c). Sandy-clay and sand sources from quaternary alluvial sediments of the Toplica river were selected and analysed as well. The analysis revealed that these specimens have a polymictic nature (Figure 10: d, e), i.e. they are marked by inclusions of diverse lithology (Maggetti 1994) and include (Figure 10: e) sedimentary, volcanic and metamorphic rocks fragments. Finally, it is relevant to mention that a formation rich of mica-schist outcrops 6-7 km east from Pločnik (Figure 10: f) could have been a suitable source for tempering materials.

\section{Discussion}

\subsection{Clay Selection and Processing}

The geological study of the sites, object of this paper, demonstrates that all of them are surrounded by sandy-clay sources suitable for ceramic production (cf. Quinn 2013: 120). Each of these sources whose composition and characteristics are compatible with those of the most common fabrics found at each site lies within $1 \mathrm{~km}$ of the supposed boundaries of the settlements.

In Gradište-Iđjoš the mineralogical composition of fabrics ID-A, ID-B and ID-C are marked by quartz, plagioclase, muscovite and minor quantities of amphibole and calcite, well matching the geology of this area of the Banat, which is characterised by abundant Pleistocene and Holocene alluvial sediments marked by fine sandy-clay with the occurrence of the same range of minerals. The clay source present in Mokrin seems to be particularly good raw material for ceramic manufacturing. This is demonstrated by its current use by the modern brick industry of this area. 
In Potporanj fabric POT-A, POT-B, POT-C could have been made from the same type of noncalcareous loessic clay that is available near to the site. On the other hand, the source of the calcareous clay (POT-D) could be found in the Pliocene formation that outcrops $5 \mathrm{~km}$ from the site that is marked by calcareous marly-clay. However, both sources of clay have not been sampled and analysed thus far. Interestingly, the samples marked by the calcareous fabric all belong to the earliest phase of the Potporanj settlement (Vinča A).

In both Gradište-Iđjoš and Potporanj, one can assume that clay originates from a common source at each respective site and was processed via cleaning (e.g. sieving and levigation, Quinn 2013: 154-156) to achieve the different degrees of coarseness, that mark each individual fabric. Alternatively, various clay sources characterised by different grain-sizes of the silty/sandy fraction could have been deliberately selected according to the type of paste the potters wanted to produce. This hypothesis will be tested through further geochemical analysis of the archaeological samples and via a systematic clay prospection around both sites. It is also important to note that both settlements are located in areas that are quite dynamic from a geomorphological perspective and their landscape, especially at Potporanj, varied considerably from the Neolithic time when large bodies of water such as Veliki Rit, Mali Rit and Vlajkovac existed in the Vršac region (Marić 2015: 39-41). The latter lies in an area that, even today, is prone to seasonal flooding. Therefore, the use of calcareous clay (POT-D) may have ceased due to landscape changes that hindered the accessibility of that specific source (Arnold 2017: 19).

Conversely, Gradište-Iđjoš is located on an alluvial plain with recent Holocene deposits that covers Pleistocene formations. Indeed, the Pleistocene clay collected at Mokrin (10 km) from the site shows closer compositional similarities to the archaeological samples in comparison to the Holocene clay collected in the immediate vicinity of the settlement. This implies that Neolithic outcrops of the Pleistocene clay, like that found in Mokrin, could have been available to the settlers of Gradište-Iđjoš.

In Belovode, samples ascribed to fabrics BEL-A, BEL-B contain fragments of metasedimentary rocks, quartz, plagioclase, muscovite, amphibole and epidote. Samples of Neogene non-calcareous sandy-clay collected close to the site have a composition comparable with the coarser fraction identified in the thin-section analysis of the ceramic samples attribute to fabric BEL-A. Therefore, this could be the source of clay used by the inhabitants of Belovode throughout the period of the settlement's occupation. On the other hand, a sandy-clay rich in shell, microfossils and calcite was also found around the site. This 
clay contains striking petrographic similarities with samples attributed to fabric BEL-B attested in Belovode from horizon 3 (Gradac phase). This indicates the use of a new clay source during the Gradac phase at Belovode.

In Pločnik, fabric PL-A (marked by sedimentary rock fragments) can be associated with clay sources immediately available in the surrounding area. As discussed above, these sandy-clay sources are both calcareous and non-calcareous and contain quartz, muscovite, and different types of sedimentary rocks. A daub sample taken from a modern-day hut located in the proximity of the archaeological site also contains a similar range of inclusions (Amicone 2017). Inhabitants of Pločnik from the start to the end of the settlement's occupation seem to have oriented themselves towards the use of non-calcareous clay sources which have good plasticity and require minimal processing. The results also show that it is possible to exclude the employment of the alluvial clay deposited by the activity of the Toplica River. As discussed above, sand samples from the river revealed to be polymictic (Maggetti 1994), with fragments of rocks of different origins (e.g. sedimentary, metamorphic and volcanic). On the other hand, specimens of fabric PL-B particularly frequent in the last phase of the site (Gradac III) are characterised by the abundant presence of muscovite and metamorphic rock inclusions in addition to fragments of sedimentary rocks. As mentioned above, suitable formations with mica-schist/gneiss outcrops would be available c. 6-7 km east from the site. The latter could have been used as source of tempering of the same type of sandy-clay used for PL-A. Alternatively, another source of clay in which fragments of mica-schist naturally occur could have been used, but was found during the raw material prospection.

Thus, the results revealed that potters at all sites selected raw materials immediately available from their surrounding landscapes. The same pattern has been observed in other Vinča settlements such as Selevac, Gomolava (Kaiser 1984: 166-173), Opovo (Tringham et al. 1992, 373), Miercurea Sibiului Petriş, Parţa (Spataro 2014) and Vinča Belo-Brdo (Spataro 2018). This behavioural tendency is not surprising, as a worldwide study of distances travelled to acquire clay and temper sources suggests that the maximum threshold distance for raw material procurement lies at $7 \mathrm{~km}$ from the potter's production place (assuming manual transport). Most, however, did not travel more than $1 \mathrm{~km}$ to obtain clay and tempers under these conditions (Arnold 2000: 343). 


\subsection{Tempering}

The four different sites analysed in this study demonstrate considerable differences in the routines of tempering i.e. the intentional addition of aplastic material into clay paste (after Quinn 2013: 156).

In both Belovode and Pločnik, tempering is not a very common practice and often not easily recognisable. In Belovode, this practice is attested sometimes in the earliest horizons and includes rock fragments and minerals tempering. From horizon 3 onwards (Gradac phase) mineral tempering does not cease to exist, but is used very sporadically, nonetheless. In Pločnik, the bimodal grain size distribution noted in some of the coarse clay samples assigned to fabric PL-A, from horizons 5 and 4, (Vinča A2/B2) could be evidence of the intentional addition of aplastic material. Also, coarse samples assigned to fabric PL-B (with mica-schist) could have been tempered. However, most samples appear to be made from minimally processed and un-tempered clay.

On the other hand, the results of the analysis carried out in Gradište-Iđjoš, and Potporanj together with the results of other studies at Vinča settlements (Kaiser 1984; Kaiser 1990; Kreiter 2011; Tringham et al. 1992: 371-377, Spataro 2014; 2017; 2018) show that tempering is a common practice among Vinča potters and that different agents were used including river sand, plant material, rocks fragments, and grog. Our study, for example, demonstrates that, in Potporanj, the preferred tempering agent for cooking vessels are plutonic and metamorphic rocks (fabric POT-A). The source of these rocks could be traced to the Vršac Mountains approximately $15 \mathrm{~km}$ from the site. This does not, however, necessitate that potters travelled to the source rock to acquire tempering agents. Rather, it is possible that debris from the production of stone tools was employed in the process of pottery production as is suggested for the mica-schist rock fabric from Pločnik (Amicone 2017: 228).

In contrast, Gradište-Iđjoš shows the use of plant and grog tempering. The former practice (plant tempering) appears to be applied only rarely. In general, in the prehistoric Balkans vessels characterised by plant tempering are usually associated with the early/middle Neolithic Starčevo phenomenon (6500-5500 cal. BC), where almost all ceramic artefacts are marked by this type of temper (e.g. Kreiter et al. 2013; Spataro 2014). A decrease in plant tempering appears to begin during the Middle Neolithic (5500-5000 cal. BC), and during the Late Neolithic it is found in only sporadically attested in with Vinča culture phenomenon such as Gradište-Iđjoš (Mirković-Marić and Amicone 2019), Gomolava (Kaiser 1984: 200) 
and Miercurea Sibiului Petriş and Parţa (Spataro 2014: 190; Spataro 2017: 67), but also in the Tisza sites (Szakmány et al. 2019: 168-169).

A special discussion deserved the use of grog, i.e. fragments of broken sherds, that is the most common type of aplastic material used in Gradište-Iđjoš. This is found in connection to both Tisza-style vessels with thick walls, and cooking pots. The same pattern has been observed in other sites of the northern Banat such as Akača-Novo Miloševo and KremenjakČoka (Mirković-Marić and Amicone 2019). Even if grog tempering has been the main tempering agent also in Gomolava, Opovo (Kaiser 1984: 198; Tringham et al. 1992: 373) it is only sporadically attested at other sites marked by the Vinča material culture (e.g. Vinča Belo Brdo, Selevac and Parţa). On the other hand, grog tempering was one of the most dominant forms of tempering in the Middle and Late Neolithic of this region (Spataro 2017: 74) and especially in the Great Hungarian Plain in connection to the Tisza material culture (Kreiter et al. 2009: 101-119; Kreiter et al. 2017b; Szakmány et al. 2019: 168). As mentioned above, the samples from Gradište-Iđjoš, presented in this paper come mostly from older museum collections and from the phase (Vinča C) of the settlement characterised by the presence of both Vinča-style and Tisza vessels (Mirković-Marić and Amicone 2019: 109). On-going analysis run by S. Amicone (as a part of separate project studying pottery technology) on ceramic samples from the new excavation and from phases securely attributed to the older occupation (end of Vinča A/beginning of Vinča B) of this settlement seems to suggest that the use of grog was already common at the site in the phases marked only by Vinča-style pottery. In addition to this, as it will be discussed below, the general impression is that the different fabric recognised at the site could be related to different functions of the vessels rather than being specific to the Vinča and Tisza material cultures.

Therefore, the use of this tempering agent does not seem to be a technological trait that is connected to the increasing presence of Tisza elements in the Late Neolithic of the Banat region, but rather to an older regional tradition going across material culture boundaries. The preference for grog in the sites of the Serbian Banat mentioned above could be explained by the fact that, apart from plant material (e.g. chaff), there are not many other available sources for tempering in a floodplain like the one that characterises the landscape of this region. Chapman (2000: 54) has also emphasised the symbolic value that could be embodied in grog tempering, suggesting that this practice was a way to incorporate ancestral material culture into new ceramic vessels. Both cultural and environmental constraints could have played a role in the decision to adopt grog as a tempering material at Gradište-Iđjoš. Future projects on 
the Vinča pottery assemblages and material culture behaviours can shed further light on this topic.

\subsection{Relationship between fabric and shape}

The correlation between vessel type and fabric is another important aspect to be considered, as it is often correlated with the emergence of specialisation (e.g. Santacreu 2014). In Pločnik, it was possible to exclude a strict relationship between fabric and vessel types. Interestingly, the grain size distribution of inclusions in dark-burnished bowls did not differ significantly from those used to produce other type of pots. On the other hand, in Belovode we can observe a tendency to select and prepare the clay paste differently, according to the type and surface treatment of the vessels. For example, most of the cooking pots were characterised by a paste rich in shell fragments, microfossils and calcite (fabric BEL-B). The selection of clay sources rich in calcite or calcite tempering in connection with cooking pots is not surprising since the presence of the calcite could have a positive impact on improving the vessel's thermal shock resistance as long as vessels are not fired above 750-800 ${ }^{\circ} \mathrm{C}$ (Rice 2005: 324; Tite and Kilikoglou 2002). At higher temperatures calcite starts to lose $\mathrm{CO}_{2}$, which is recovered during the cooling phase. This process of $\mathrm{CO}_{2}$ loss and recovery results in a decrease and a subsequent increase of calcite volume. As clay undergoes a shrinkage process during firing, the re-formed calcite no longer has enough space within the ceramic matrix, thus leading to the destruction of the ceramic vessel (Picon 1995).

Conversely, bowls and small amphorae which are in most cases burnished or polished, have a fine fabric (fabric BEL-A2) that could indicate that a finer clay source (ideal for burnishing) was used to manufacture these vessels, or that the starting raw material was freed of its coarser fraction through sieving or levigation. The same pattern has been noticed in Potporanj and Gradište-Iđjoš where burnished bowls and small amphorae are characterised by extremely fine fabrics. Similar patterns are also seen at other Vinča sites (Spataro 2017: 67). On the other hand, cooking and storage vessels (pithoi and large amphorae) are tendentially tempered at these two sites as in most of the other Vinča settlements (Kaiser 1984: 196; Spataro 2017; 2018).

Therefore, the results of this study indicate the use of specific patterns of tempering according to specific vessel types at some Vinča sites. Vessels with thicker walls, such as large amphorae and pithoi, are characterised by the presence of coarse tempering, whereas 
many vessels with finer fabrics (e.g. burnished bowls and small amphorae) often have thinner walls. These are the general tendencies observed in the preparation of ceramic pastes at the Vinča sites included in this study.

\subsection{Exploring similarities and differences}

Overall, our results demonstrate the presence of several technological traits that are common within the Vinča assemblage with significant differences that appear to support notions of regionalism. Pottery assemblages also demonstrate the presence of traits that vary locally within the technological traditions of Vinča pottery production (Spataro 2017: 76). In all settlements included in this study, potters tend to prefer non-calcareous clay sources to calcareous clays (Spataro 2017, 64), even if both types are often available in their environment (for a definition of calcareous clay see Maniatis and Tite 1981: 61). The caveats associated with the use of calcitic clay pastes are well known as discussed above. The firing of calcareous clay, depending on the grain size of calcite inclusions, challenges potters to control the firing temperature within their firing installations. Therefore, the preference for non-calcareous clay sources could be a means of reducing efforts to monitor and control the firing process during ceramic production. These issues contribute to on-going discussions regarding pyrotechnological skills in the Vinča culture and regarding the nature of firing installations, such as kilns in Vinča settlements (e.g. Amicone 2017; Spataro 2017; 2018; Vuković 2018). It is likely that pyrotechnogical traditions could have varied based on settlements, but a thorough exploration of this issue needs to be addressed in further investigations. The study of the ceramics from Belovode and Pločnik suggests that, despite a certain degree of awareness of thermal properties, potters were not always in perfect control of firing temperatures and conditions (e.g. Amicone 2017; forthcoming).

Our study also demonstrates that in all sites, there is a tendency to select, process or temper clay sources to achieve different degree of paste coarseness, that are correlated to the thickness of the vessels produced. Tempers, when used, are often associated with cooking pots and storage vessels and were likely added for functional reasons such as to reduce shrinkage during the drying process and to increase thermal shock resistance (Rice 2005). However, the degree of connection between fabric and shape/function and the choice of a temper type varies among the different sites taken into consideration. This results in a scenario of different technological choices (van der Leeuw 1993) that could reflect specific 
regional technological traditions marked by varying degrees of specialisation. It is undeniable that the selection of a specific temper is affected by environmental constraints. However, the fact that once a type of temper is adopted within Vinča settlements, is tendentially used until the end of its occupation, thereby suggesting that this technological trait became part of the craft tradition of that community of practice (Picon and Wenger 1991; Wenger 1998). In general, the strong conservative technological traditions also visible in other aspects of pottery making (e.g. forming technique and firing) that seems to mark Vinča potting communities (Amicone 2017; forthcoming;) suggests very tight and conservative learning networks (e.g. vertical and direct transmission from parents to offspring, see Cavalli-Sforza and Feldman 1981) that could have operated not only on a chronological scale, but also on spatial level. For example, it has been observed (Amicone 2017) that pottery from other Neolithic Vinča sites found in the vicinity of Pločnik (Kuzmanović-Cvetković 1998) show a strong similarity to the technological traits with the production of Pločnik itself. Livingstone Smith's (2000) work on clay processing for pottery in northern Cameroon suggests that patterns of technical variations seem to correspond to certain geographically-definable areas (e. g. 'people of the west bank of the Faro' or 'people around Poli'). Therefore, the level of social interaction and transmission of technological information appears to be correlated to settlement patterns and population density. Within material cultures, some traits like artefact morphology and decorations indeed resonate on a wider geographical scale. These are often based on processes of imitation that do not necessarily imply direct contact among people (Roux 2015). On the other hand, some traits, such as production techniques, rely on interpersonal interactions and direct technical guidance and are connected to local developments that can help trace tighter networks among people (Kroon et al. 2019; Roux 2015). It is possible that similar mechanisms, based on interactions among people that were influenced by spatial propinquity, were operating within Vinča communities, thus generating the pattern of regional variability seen in the archaeological record. However, these networks may also reflect kinship webs (Kienlin 2010; Radivojević and Rehren 2016: 233) and most likely both aspects could be responsible for the definition of the pattern of technical similarities observed. In such cases, relatively large-scale and loose networks based on indirect transmission would be responsible for the general similarities seen in the pottery making traditions of Vinča pottery communities and, more generally, in the material cultures of the central Balkans. 


\section{Conclusions}

By emphasising the traditions associated with the selection and processing of raw materials for pottery making in Vinča culture sites, our study demonstrates the value of approaching the problem of similarities and differences in material culture from a ceramic technological prospective. Vinča ceramics producers therefore represent several diverse communities of practice which share some common technological traits resonating over a wide geographical and temporal range. However, they are also marked by characteristics that reflect tight learning networks defined by strong traditions developed in a constant dialogue between people and their landscape. The lack of systematic microregional studies within Vinča culture research do not allow for a thorough assessment of the extension and the connection among these regional technological patterns. In addition, more systematic assessments of all aspects of pottery production including forming techniques and firing traditions should be taken in account. Despite these limits, our study presents a meaningful hypothesis on the mechanism governing the diffusion of ideas that catalyse the formation of similarities and diversity in material cultures.

\section{Acknowledgments}

The authors are indebted to all those who contributed to the archaeological excavation of Belovode, Pločnik, Gradište-Iđjoš and Potporanj. Financial support for this research has been generously provided by the Arts and Humanities Research Council (AHRC), the Institute for Archaeo-Metallurgical Studies (IAMS), the Funds for Women Graduates (FfWG), the Excellence Initiative of the Eberhard Karls Universität Tübingen and the Ministry for Science, Research and Art of Baden-Württemberg. We would like to thank Gordana Grabez, Dusko Sljivar and the National Museum in Belgrade for securing access to materials from Belovode and Pločnik. We are also indebted to Christoph Berthold, Enrica Bonato, Enrico Croce, Lars Heinze, Timothy Kaiser, Tobias Kiemle, Tobias Kienlin, Evangelia Kiriatzi, Attila Kreiter, Robert Mason, Lionello Morandi, Jugoslav Pedić, Patrick Quinn, Miljana Radivojević, Thilo Rehren, Michela Spataro and Jasna Vuković for their help and feedback over the years. 


\section{Author contributions}

Silvia Amicone: conceptualisation, funding acquisition, investigation, methodology, archaeometric analyses and their interpretation, writing (original draft). Arvin Raj Mathur: investigation, methodology, petrographic analysis of samples from Potporanj (under the supervision of Silvia Amicone) editing and reviewing (original draft). Rengasamy Deepthi Pavitra: investigation, methodology, petrographic analysis of sample from Potporanj (under the supervision of Silvia Amicone) editing and reviewing (final draft). Neda Mirković-Marić: investigation, methodology, archaeological background editing and reviewing (final draft). Ivana Pantović: investigation, methodology, archaeological background editing and reviewing (final draft). Julka Kuzmanović-Cvetković: investigation, methodology, archaeological background editing and reviewing (final draft).

\section{References}

Amicone, S. 2017. Pottery Technology at the Dawn of the Metal Age: A view from Vinča Culture. Unpublished Ph.D. thesis, University College London.

Amicone, S., Radivojević, M., Quinn, P. S., Berthold, C. and Rehren, Th. (forthcoming). Pyrotechnological Connections? Re-investigating the Link between Pottery Firing Technology and the Origins of Metallurgy in the Vinča Culture, Serbia. Journal of Archaeological Science.

Arnold, D. E. 1993. Ecology and Ceramic Production in an Andean Community. Cambridge, Cambridge University Press.

Arnold, D. E. 2000. Does the standardization of ceramic pastes really mean specialisation? Journal of Archaeological Method and Theory 7(4), 333-375.

Arnold, D. E. 2017. Raw material selection, landscape, engagement, and paste recipes: Insights from ethnoarchaeology. In: L. Burnez-Lanotte (ed.), Matières à Penser. Raw Materials Acquisition and Processing in Early Neolithic Pottery Productions. Proceedings of the Workshop of Namur (Belgium), 29-30 May 2015. Paris, Société Préhistorique Française. 
Breunig, P. 1987. ${ }^{14}$ C-Chronologie des vorderasiatischen, südost- und mitteleuropäischen Neolithikums. Köln, Böhlau.

Brukner, O. 1960 Potporanj - Kremenjak, Utrine. Belgrade, Starinar (book 11).

Brukner, B. 1968. Neolit $u$ Vojvodini (The Neolithic in Vojvodina). Dissertationes V, Beograd-Novi Sad, Vojvodanski Muzej.

Carlton, R. 2019. Tempering expectations: What do West Balkan potters think they are doing? In: Amicone, S., Quinn, P. S., Marić, M., Mirković-Marić, N., Radivojević, M. (eds), Tracing Pottery Making Recipes in the Balkans 6th-4th Millennia BC. Oxford, Archaeopress, 8-24.

Cavalli-Sforza, L. L. and Feldman, M. 1981. Cultural Transmission and Evolution: A Quantitative Approach. Princeton (NJ), Princeton University Press.

Chapman, J. 1981. Vinča Culture of South-East Europe: Studies in Chronology, Economy and Society. Oxford, British Archaeological Reports.

Chapman, J. 2000. Fragmentation in Archaeology. People Places and Broken Objects in the Prehistory of South Eastern Europe. London, Routledge.

Dimitrijević, M. D. 1997. Geology of Jugoslavia. Belgrade, Geological Insitute GEMINI.

Ehrich, R. W. and Bankoff, H. A. 1992. East central and southeastern Europe. In: R. W. Ehrich (ed.), Chronologies in Old World Archaeology. Chicago (IL), University of Chicago Press, 341-375.

Garašanin, M. 1951. Hronologija vinčanske grupe (Chronology of the Vinča Group). Ljubljana, Univerza v Ljubljani.

Garašanin, M. 1979. Centralno balkanska zona (The central Balkans zone). In: A. Benac (ed.), Praistorija Jugoslavenskih Zemalja II (Prehistory of Yugoslav countries II). Sarajevo, Svjetlost, 79-212. 
Garašanin, M. 1993. Zu den Problemen der Vinča-Gruppe in Rumänien. Balcanica 24, 7-20.

Gosselain, O. P. and Livingstone Smith, A. 2005. The source: Clay selection and processing practices in Sub-Saharan Africa. In: A. Livingstone Smith, D. Bosquet and R. Martineau (eds), Pottery Manufacturing Process: Reconstruction and Interpretation. Oxford, Archaeopress.

Grbić, M. 1929. Pločnik, eine Prähistorische Ansiedlung aus der Kupferzeit. Belgrade, National Museum Belgrade.

Jovanović, B. 1993/1994. Gradac phase in the relative chronology of the late Vinča culture. Starinar 43/44, 1-12.

Kaiser, T. 1984. Vinča Ceramics: Economic and Technological Aspects of Late Neolithic Pottery Production in Southeast Europe. Unpublished Ph.D. thesis, University of California, Berkley.

Kaiser, T. 1989. Steatite-tempered pottery from Selevac, Yugoslavia: A Neolithic experiment in ceramic design. Archaeomaterials 3(1), 1-10.

Kaiser, T. 1990. Ceramic technology. In: R. E. Tringham and D. Krstiš (eds.), Selevac: A Neolithic Village in Yugoslavia. Los Angeles, University of California Press, 255-287.

Kienlin, T. L. 2010. Traditions and Transformations: Approaches to Eneolithic (Copper Age) and Bronze Age Metalworking and Society in Eastern Central Europe and the Carpathian Basin. Oxford, Archeopress.

Koprivica, D. and Strajin, V. 1994. The Basic Geological Map of the Federal Republic Yugoslavia. Kikinda Sheet (L34-077). Belgrade, Federal Ministry of Economy of the SFRY, Geomap. 
Kreiter, A., Szakmány, Gy. and Kázmér, M. 2009. Ceramic technology and social process in late Neolithic Hungary. In: P. Quinn (ed.), Interpreting Silent Artefacts: Petrographic Approaches to Archaeological Ceramics. Oxford, Archaeopress, 101-119.

Kreiter, A., Azbej Havancsák I., Sipos, P., Tóth M. and Orsolya, V. 2011. Maroslele-Panáról származó neolitikus kerámia töredékek petrográfiai, XRF és XRD vizsgálata. (The petrographic, XRF and XRD analyses of the Neolithic pottery from Maroslele-Pana). In: T. Paluch (ed.), Maroslele-Pana. Egy Középső Neolitkus Lelöhely a Kultúrák Határvidékén. Szeged, Móra Ferenc Múzeum, 303-326.

Kreiter, A., Pető, Á. and Pánczél, P. 2013. Materializing tradition: Ceramic production in Early and Middle Neolithic Hungary. In: E. Bánffy (ed.), The Early Neolithic of the DanubeTisza Interfluve. Oxford, Archaeopress, 127-140.

Kreiter, A., Marton, T., Gomart, L., Oross, K. and Pánczél, P. 2017a. Looking into houses: Analysis of LBK ceramic technological change on a household level. In: L. Burnez-Lanotte (ed.), Matières à Penser. Raw Materials Acquisition and Processing in Early Neolithic Pottery Productions. Proceedings of the Workshop of Namur (Belgium), 29-30 May 2015. Paris, Société Préhistorique Française. 111-132.

Kreiter, A., Kalicz, N., Kovács, K., Siklósi, Zs. and Viktorik, O. 2017b. Entangled traditions: Tisza and Lengyel ceramic technology in a Late Neolithic settlement in northern Hungary. Journal of Archaeological Science: Reports 16, 285-295.

Kreiter, A., Marton, T., Oross, K. and Pánczél P. 2019. Looking into Pots: Understanding Neolithic ceramic technological variability from Western Hungary. In: Amicone, S., Quinn, P. S., Marić, M., Mirković-Marić, N., Radivojević, M. (eds), Tracing Pottery Making Recipes in the Balkans 6th-4th Millennia BC. Oxford, Archaeopress, 65-77.

Kroon, E. J., Huisman, D. J., Bourgeois, Q. P. J., Braekmans, D. J. G. and Fokkens, H. 2019. The introduction of Corded Ware Culture at a local level: An exploratory study of cultural change during the Late Neolithic of the Dutch West Coast through ceramic technology. Journal of Archaeological Science: Reports 26, 1-21. 
Kuzmanović-Cvetković, J. 1998. Prokuplje, grad sv. Prokopija (Prokuplje, Castle St. Procopius). Prokuplje, Narodni Muzej Toplice.

Lave, J. and Wenger E. 1991. Situated Learning: Legitimate Peripheral Participation. Cambridge University Press, Cambridge.

Lazarovici G. 1979. Neoliticul Banatului (The Neolithic of Banat). Cluj-Napoca, Bibliotheca Musei Napocensis IV.

van der Leeuw, S. E. 1993. Giving the potter a choice: Conceptual aspects of pottery techniques. In: P. Lemonnier (ed.), Technological Choices: Transformations in Material Cultures since the Neolithic: 238-288. London, Routledge.

Livingstone Smith, A. 2000. Processing clay for pottery in Northern Cameroon: Social and technical requirements. Archaeometry 42: 21-42.

Maggetti, M. 1994. Mineralogical and petrographical methods for the study of ancient pottery. In: F. Buragato, O. Grubessi and L. Lazzarini (eds), 1st European Workshop on Archaeological Ceramics. Rome, Università degli Studi di Roma La Sapienza, 23-35.

Malešević, M., Vukanović, M., Brković, T., Obra Dinović, Z., Karajičić L., Stanisavljević, R., Dimi Trijević, M. and Urošević, M. 1980. The Basic Geological Map of the Federal Republic Yugoslavia. Kursumlija Sheet (L34-031). Belgrade, Federal Ministry of Economy of the SFRY, Geomap.

Maniatis, Y. and Tite, M. S. 1981. Technological examination of Neolithic Bronze-Age pottery from Central and Southeast Europe and from the Near-East. Journal of Archaeological Science 8, 59-76.

Marić, M. 2015. Modelling obsidian routes during Late Neolithic in the South-East Banat region of Vršac using GIS. Starinar 45, 37-52. 
Marić, M., Mirković-Marić, N., Molloy, B., Jovanović, D., Mertl, P., Milašinović, L. and Pendić, J. 2016. New results of the archaeological excavations on the site Gradište near Iđoš: Season 2014. Glasnik Srpskog Arheološkog Društva 32, 125-144.

Michelaki, K. V., Braun G. and Hancock, G. V. 2014. Local clay sources as histories of human-landscape interactions: a ceramic taskscape perspective. Journal of Archaeological Method and Theory 22(3), 783-827.

Milleker, F. 1934. Die steinzeitlichen Funde von Potporanj bei Vršac: Zugleich Fundbericht. Vršac, Kirchner.

Milleker, F. 1938. Vorgeschicht des Banat. Starinar 13, 102-166.

Milojčić, V. 1949. Chronologie der jüngeren Steinzeit Mittel- und Südosteuropas. Berlin, Mann.

Mirković-Marić, N. and Marić, M. 2017. Late Neolithic Tisza sites in the Serbian part of Banat. Archaeologia Értesítő 142: 1-34.

Mirković-Marić, N. and Amicone, S. 2019. Technological variances between Tisza and Vinča pottery. In: Amicone, S., Quinn, P. S., Marić, M., Mirković-Marić, N., Radivojević, M. (eds), Tracing Pottery Making Recipes in the Balkans 6th-4th Millennia BC. Oxford, Archaeopress, 96-112.

Pantović, I. 2013. Vinča Amulets - Southeast Banat. Vršac, City Museum Vršac.

Picon M. 1995. Grises et grises: quelques réflexions sur la céramiques cuites en mode B. In: Actas das las Jornada de Ceramica Medieval e Pos-Medieval. Porto. Maio, Municipal de Tondela, 283-292.

Quinn, P. S. 2013. Ceramic Petrography. The interpretation of Archaeological Pottery and Related Artefacts in Thin Section. Oxford, Archeopress. 
Radivojević, M. and Grujić, J. 2018. Community structure of copper supply networks in the prehistoric Balkans: An independent evaluation of the archaeological record from the 7 th to the 4th millennium BC. Journal of Complex Networks 6, 106-124.

Radivojević, M. and Kuzmanović-Cvetković, J. 2014. Copper minerals and archaeometallurgical materials from the Vinča culture sites of Belovode and Pločnik: Overview of the evidence and new data. Starinar 64, 8-30.

Radivojević, M. and Rehren, Th. 2016. Paint it black: The rise of metallurgy in the Balkans. Journal of Archaeological Method and Theory 22, 200-237.

Radivojević, M., Rehren, Th., Pernicka, E., Šljivar, D., Brauns, M. and Borić, D. 2010. On the origins of extractive metallurgy: New evidence from Europe. Journal of Archaeological Science 37, 2775-2787.

Radivojević, M., Rehren, Th., Kuzmanović-Cvetković, J., Jovanović, M. and Northover, J. P. 2013. Tainted ores and the rise of tin bronze metallurgy, c. 6500 years ago. Antiquity 87, 1030-1045.

Radivojević, M., Roberts, B. W., Kuzmanović-Cvetković, M., Marić, M. and Rehren, Th. (eds) forthcoming. The Rise of Metallurgy in Eurasia: The Archaeology of Early Metallurgy and Society in the Central Balkans. London, UCL Press.

Rice, P. M. 2005. Pottery Analysis: A Sourcebook. Chicago (IL), University of Chicago Press.

Roux, V. 2015. Standardization of ceramic assemblages: Transmission mechanisms and diffusion of morpho-functional traits across social boundaries. Journal of Anthropological Archaeology 40, 1-9.

Roux, V. 2017. De céramiques et des hommes. Décoder les asseblages archéologiques. Paris, Presses universitaires de Paris Nanterre. 
Santacreu, D. A. 2014. Materiality, Techniques and Society in Pottery Production. The Technological Study of Archaeological Ceramics through Paste Analysis. Warsaw/Berlin, De Gruyter.

Schier, W. 2000. Measuring change: The Neolithic pottery sequence of Vinča-Belo Brdo. Documenta Praehistorica 27, 187-197.

Šljivar, D. and Jacanović, D. 1996a. Veliko Laole - Belovode: The settlement of the culture of Vinča. Glasnik Srpskog archeološkog društva 12, 55-60.

Šljivar, D. and Jacanović, D. 1996b. Veliko Laole - Belovode. Vinča culture settlement in northeastern Serbia. Préhistorie Européene 8, 175-188.

Šljivar, D. and Jacanović, D. 1997. Veliko Laole - Belovode: The settlement of the Vinča culture. Glasnik Srpskog archeološkog društva 13, 115-125.

Šljivar, D. and Kuzmanović-Cvetković, J. 1997. Pločnik near Prokuplje: The Vinča culture settlement. Glasnik Srpskog archeološkog društva 13, 103-113.

Šljivar, D. and Kuzmanović-Cvetković, J. 1998. Pločnik near Prokuplje: Excavation in 1997. Glasnik Srpskog archeološkog društva 14, 79-85.

Spataro, M. 2014. Continuity and change in pottery manufacture between early and middle Neolithic of Romania. Archaeological and Anthropological Sciences 6(2), 175-197.

Spataro, M. 2017. Innovation and regionalism in the Middle/Late Neolithic of south and south-eastern Europe (ca. 5,500-4,500 cal. BC): A ceramic perspective. In: L. Burnez-Lanotte (ed.), Matières à Penser. Raw Materials Acquisition and Processing in Early Neolithic Pottery Productions. Proceedings of the Workshop of Namur (Belgium), 29-30 May 2015. Paris, Société Préhistorique Française, 61-72.

Spataro, M. 2018. Origins of specialization: The ceramic chaîne opératoire and technological take-off at Vinča-Belo Brdo, Serbia. Oxford Journal of Archaeology 37(3), 247-265. 
Stalio, B. 1962. Pločnik-Prokuplje naselje vinčanske grupe (The Pločnik-Prokuplje settlement of the Vinča group). Arheološki Pregled 4, 19-25.

Szakmány, Gy., Vanicsek, K., Bendő, Z., Kreiter, A., Pető, A., Lisztes-Szabó, Z. and Horváth, F. 2019. Petrological analysis of Late Neolithic ceramics from the Tell Settlement of Gorzsa (South-East Hungary). In: Amicone, S., Quinn, P. S., Marić, M., Mirković-Marić, N., Radivojević, M. (eds), Tracing Pottery Making Recipes in the Balkans 6th-4th Millennia BC. Oxford, Archaeopress, 156-171.

Tite, M. S. and Kilikoglou, V. 2002. Do we understand cooking pots and is there an ideal cooking pot? In: V. Kilikoglou, A. Hein and Y. Maniatis (eds), Modern Trends in Scientific Studies on Ancient Ceramics. Oxford, Archaeopress, 1-8.

Tite, M. S., Kilikoglou V. and Vekinis G. 2001. Strength, toughness and thermal shock resistance of ancient ceramics, and their influence on technological choice. Archaeometry 43, 301-324.

Tringham, R. E., Brukner, B., Kaiser, T., Borojević, K., Bukvić L., Šteli, P., Russel, N., Stafanović, M. and Voytek, B. 1992. Excavation at Opovo, 1985-1987: Socioeconomic change in the Balkans Neolithic. Journal of Field Archaeology 19, 351-386.

Tripković, B. and Milić, M. 2008. The Origin and Exchange of Obsidian from Vinča-Belo Brdo. Starinar 58, 71-86.

Vujisić, T., Navala, M., Lončarević, Č., Kalenić, M. and Hadži-Vuković 1977. The Basic Geological Map of the Federal Republic Yugoslavia. Kursumlija Sheet (L34-139). Belgrade, Federal Ministry of Economy of the SFRY, Geomap.

Vuković, A., Ivković, A. and Nikolić, J. 1970. The Basic Geological Map of the Federal Republic Yugoslavia. Vršac (L 34-103). Belgrade, Federal Ministry of Economy of the SFRY, Geomap.

Vucović, J. B. 2011. Late Neolithic pottery standardization. Application of statistical analysis. Glasnik Srpskog archeološkog društva 27, 81-101. 
Vuković, J. 2018. Late Neolithic Vinča pottery firing procedure. Opuscula Archaeologica 39(40), 25-35.

Wenger, E. 1998. Communities of Practice. Learning, Meaning, and Identity. New York, Cambridge University Press.

Whittle, A., Bayliss, A., Barclay, A., Gaydarska, B., Bánffy, E., Borić, D., Draşovean, F., Jakucs, J., Marić, M., Orton, D., Pantović, I., Schier, W., Tasić, N. and Vander Linden, M. 2016. A Vinča potscape: Formal chronological models for the use and development of Vinča ceramics in South-East Europe. Documenta Praehistorica 43, 1-60.

Whitbread, I. K. 1995. Greek Transport Amphorae: A Petrological and Archaeological Study. Athens: British School at Athens. Athens, British School at Athens. 